\title{
SYSTEMATIC LITERATURE REVIEW OF CLINICAL MANAGEMENT FOR R/R AML
}

\author{
V.L Lim \\ Nanyang Technological University \\ Singapore
}

Abstract - The aim of this SLR was to systematically review clinical guidelines providing treatment recommendations for the management of R/R AML. The literature search to identify clinical guidelines and studies on clinical practice identified 872 references of which 817 were unique. After the initial screening of titles and abstracts, 47 references were considered as potentially relevant. Following detailed examination of the full articles, 14 publications were included for abstraction. Of these, two were available as abstracts only. Overall, 12 guidelines and two evidencebased reviews of the current management of $R / R$ AML were included in the literature review. All guidelines provide similar recommendations regarding therapeutic options for R/R AML, and include salvage therapy, offering participation in a clinical trial with new interventions, and BMT. The literature review highlights the lack of specific recommendations for the treatment of patients with FLT3+ R/R AML. NCCN guidelines are the only ones that provide specific therapies for these patients.

Keywords - Literature review, FLT3+ R/R AML, clinical guidelines, treatment recommendation, therapeutic options

\subsection{OBJECTIVES OF THE CLINICAL MANAGEMENT REVIEW}

The aim of this SLR was to systematically review clinical guidelines providing treatment recommendations for the management of R/R AML in the EU5, Japan and the US and to identify evidence regarding how these patients are treated in clinical practice in these countries.

\subsection{METHODS OF THE CLINICAL MANAGEMENT REVIEW}

\subsubsection{Research question}

The research questions addressed in the SLR of clinical management of R/R AML were:

- What are the treatment guidelines for R/R AML in the countries of interest?

- What is the current treatment pathway for patients with $\mathrm{R} / \mathrm{R}$ AML in clinical practice in these countries?

\subsubsection{Literature search}

\subsubsection{Bibliographic database search strategies}

The search strategy used for the management review is presented in Appendix I. The search strategy was adapted for each database searched, however the key strategy remained as follows: "disease terms" AND "endpoints".

\subsubsection{Electronic databases and information sources}

In line with the recommendations from the Centre for Reviews and Dissemination (CRD) [CRD 2009] and the National Institute for Health and Care Excellence (NICE) [NICE 2015], the searches for the SLR of clinical management were conducted in the following databases:

- Medline and Medline in Process

- Embase

- Cochrane Database of Systematic Reviews (CDSR).

In addition, the websites of country-specific oncology or haematology associations were searches for clinical guidelines up to December 01, 2018. These websites included those for:

- NCCN: https://www.nccn.org/

- American Society of Clinical Oncology (ASCO): http://www.asco.org/

- American Society of Hematology (ASH): http://www.hematology.org/

- European Hematology Association (EHA): https://ehaweb.org/

- European Society for Medical Oncology (ESMO): http://www.esmo.org/

- ELN: https://www.leukemianet.org/content/home/index_eng.html

\subsubsection{Study selection}

\subsubsection{Eligibility criteria}

This systematic review was conducted according to the principles of systematic reviewing as set out in the guidance published by the CRD [CRD 2009] and NICE guidance [NICE 2015]. To identify relevant evidence, a clear definition of the study participants, interventions, comparison groups, outcomes and study types of interest are required. These so-called PICOS (population, intervention, comparator, outcome, study design) criteria are provided in Table 31. 


\section{International Journal of Engineering Applied Sciences and Technology, 2020 \\ Vol. 4, Issue 9, ISSN No. 2455-2143, Pages 61-83 \\ Published Online January 2020 in IJEAST (http://www.ijeast.com)}

The geographic scope was limited to EU5, Japan, and the US. The population scope was R/R AML.

In terms of population, publications addressing the recommended or prescribed treatment pathway for adult patients ( $\geq 18$ years) with $\mathrm{R} / \mathrm{R}$ AML (as described above) were eligible for inclusion in this review. Special focus was given to the population with FLT3+ R/R AML.

The searches were not restricted to any intervention but encompassed all therapies recommended or prescribed for the management of $\mathrm{R} / \mathrm{R}$ AML in the countries of interest. No comparators were considered in the searches.

The outcomes of interest were treatment recommendations in clinical guidelines and prescription behaviour in clinical practice. Special focus was given to recommendations for FLT3+ R/R AML.

In terms of study design, clinical guidelines focusing either exclusively or partially on the management of R/R AML for the countries of interest were included in the review. Cross-sectional studies, prescription behaviour or practice studies and observational studies were also eligible for inclusion.

Table 0-1 Clinical guidelines and clinical practice review scope - inclusion and exclusion criteria

\begin{tabular}{|c|c|c|}
\hline PICOS & Inclusion criteria & $\begin{array}{l}\text { Exclusion } \\
\text { criteria }\end{array}$ \\
\hline $\begin{array}{l}\text { Population of } \\
\text { interest }\end{array}$ & $\begin{array}{l}\text { Adult patients ( } \geq 18 \\
\text { years) with } R / R \text { AML }\end{array}$ & $\begin{array}{l}\text { - Children } \\
\text { - Newly } \\
\text { diagnosed } \\
\text { AML }\end{array}$ \\
\hline $\begin{array}{l}\text { Interventions } \\
\text { of interest }\end{array}$ & $\begin{array}{l}\text { All treatments either } \\
\text { recommended or } \\
\text { prescribed for } \\
\text { management of R/R AML }\end{array}$ & - \\
\hline $\begin{array}{l}\text { Comparators } \\
\text { of interest }\end{array}$ & Not applicable & - \\
\hline $\begin{array}{l}\text { Outcomes of } \\
\text { interest }\end{array}$ & $\begin{array}{l}\text { - Treatment } \\
\text { recommendations } \\
\text { - Prescription practice in } \\
\text { clinical practice }\end{array}$ & - \\
\hline $\begin{array}{l}\text { Study designs } \\
\text { of interest }\end{array}$ & $\begin{array}{l}\text { - SLRs } \\
\text { - Clinical guidelines } \\
\text { including those of } \\
\text { international } \\
\text { haematological and } \\
\text { oncological } \\
\text { associations } \\
\text { - Cross-sectional or } \\
\text { observational studies } \\
\text { on prescription } \\
\text { behaviour }\end{array}$ & $\begin{array}{l}\text { - Publications } \\
\text { pre-2003 } \\
\text { - Expert opinion }\end{array}$ \\
\hline
\end{tabular}

Abbreviations: AML: acute myeloid leukaemia; PICOS: population, intervention, comparator, outcome, study design; R/R: relapsed / refractory; SLR: systematic literature review.

\subsubsection{Limits}

In order to refine the search, the clinical management review was limited to:

\section{- Publication date: last 15 years}

- Countries of interest: EU5, Japan, and the US

- Languages included: due to expected limited availability of data, no language restriction were applied except for treatment guidelines in Japan. For the latter (i.e., guidelines in Japan) only those relevant guidelines available in English were reviewed and included in this SLR.

The publication timeframe was limited to the last 15 years only because this period was sufficiently long to capture the most recent clinical guidelines. For the purpose of this review, guidelines published earlier than 2003 were considered no longer relevant given all the changes the treatment paradigm has undergone in the last decade.

\subsubsection{Study selection process}

During the initial study selection, articles were rapidly assessed and categorised according to relevance in meeting the eligibility criteria. This stage involved removing obviously irrelevant records (such as animal studies, editorials, case reports and studies of conditions and interventions outside of the systematic review scope). The number of records removed at this stage was recorded. This process was undertaken by two experienced information specialists.

After the removal of the obviously irrelevant records, the remaining records were assessed in more detail to select those meeting the review eligibility criteria. This assessment was undertaken by one researcher and reviewed by a second researcher. If there was uncertainty about the relevance of a record based on the abstract, a full copy of the publication was obtained.

Once the full text of articles was obtained, they were assessed in detail for relevance to the eligibility criteria and the final selection of studies to inform the reviews were made.

At the end of the selection process, a list of included and excluded studies identified through the searches were prepared.

\subsubsection{Data extraction strategy}

Quality assessment and data extraction were carried out by one reviewer with quality checking undertaken on all records by a second reviewer. Any discrepancies were to be resolved by a third reviewer.

A data extraction form was designed to document the characteristics and outcomes of the selected studies [Higgins 2011]. The list of items included in the data abstraction form is 


\section{International Journal of Engineering Applied Sciences and Technology, 2020 \\ Vol. 4, Issue 9, ISSN No. 2455-2143, Pages 61-83 \\ Published Online January 2020 in IJEAST (http://www.ijeast.com)}

presented in Error! Reference source not found.. Once all relevant studies had been identified, the relevant data were extracted and included in the data extraction form.

\subsubsection{Quality assessment and risk of bias in included studies}

Quality/risk of bias of each of the included studies was assessed by one reviewer with quality assessment undertaken on all records by a second reviewer. Any discrepancies were resolved through discussion or by consulting a third reviewer.

\subsubsection{Data analysis}

The format of the full review report conforms to Preferred Reporting Items for Systematic Reviews and Meta-Analysis (PRISMA) reporting guidance (see Appendix IV) [Moher 2009].

\subsection{RESULTS OF THE CLINICAL MANAGEMENT REVIEW}

\subsubsection{Studies flow for searches to identify clinical guidelines}

The literature search to identify clinical guidelines and studies on clinical practice identified 872 references of which 817 were unique (Error! Reference source not found.).

After the initial screening of titles and abstracts, 47 references were considered as potentially relevant. Following detailed examination of the full articles, 14 publications were included for abstraction. Of these, two were available as abstracts only.

Among those guidelines excluded from the review, the NICE pathways merit special mention. The NICE pathways for myeloid leukaemia does not address R/R AML. The pathway recommends:

- Gemtuzumab, with daunorubicin and cytarabine, for untreated de novo CD33 mutation positive (CD33+) AML, except APL, in people 15 years and over, only if they start induction therapy when either the cytogenetic test confirms that the disease has favourable, intermediate or unknown cytogenetics (that is, because the test was unsuccessful) or when their cytogenetic test results are not yet available and they start consolidation therapy when their cytogenetic test confirms that the disease has favourable, intermediate or unknown cytogenetics (because the test was unsuccessful) [NICE pathways].

- Midostaurin as an option for treating adults with newly diagnosed FLT3+ AML in combination with standard daunorubicin and cytarabine as induction therapy, in combination with high-dose cytarabine as consolidation therapy, and as monotherapy after CR as maintenance therapy [NICE pathways].
- Azacitidine for patients with AML who are ineligible for HSCT and have 20-30\% blasts and multilineage dysplasia, according to the WHO classification [NICE pathways]. Azacitidine is not recommended for treating patients with AML with more than $30 \%$ bone marrow blasts in patients of 65 years or older who are not eligible for HSCT [NICE pathways].

- In addition, several guidelines were identified for Canada but have not been abstracted because Canada was not within the remit of this SLR. The identified guidelines are:

- Brandwein et al (2013) which report the consensus from Canadian experts on the treatment of older patients with AML [Brandwein 2013]. This consensus was updated in 2017 [Brandwein 2017]

- $\quad$ The Alberta Health Services guideline* [AHS 2018]

- The Leukaemia/Bone Marrow Transplant Program of $\mathrm{BC}^{\dagger}$ [BC BMT 2018]

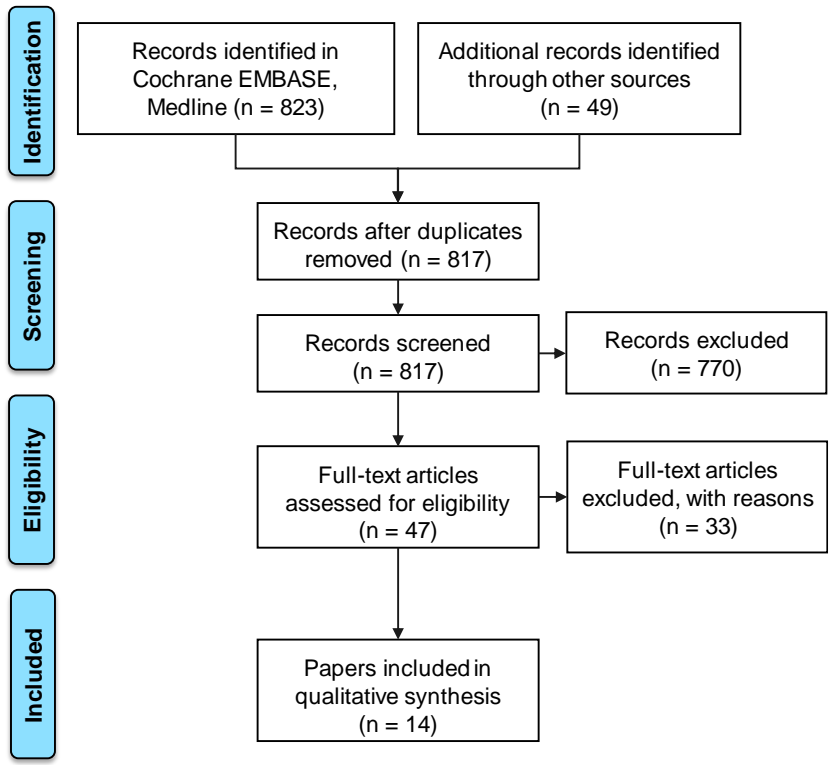

Fig. 3-1 PRISMA flow diagram for the clinical management review

\subsubsection{What are the treatment guidelines for R/R AML?}

An overview of the treatment guidelines selected for this review is provided in
*Available at https://www.albertahealthservices.ca/assets/info/hp/cancer/if-hpcancer-guide-lyhe006-aml.pdf. Accessed on December 02, 2018, $\dagger$ Available at http://www.leukemiabmtprogram.com/index.html. Accessed on December 02, 2018. 


\section{International Journal of Engineering Applied Sciences and Technology, 2020 \\ Vol. 4, Issue 9, ISSN No. 2455-2143, Pages 61-83 \\ Published Online January 2020 in IJEAST (http://www.ijeast.com)}

Table 0-1.

The SLR identified 12 relevant guidelines and two evidencebased reviews of the current management of R/R AML. The reviewed guidelines included:

- Two guidelines with US coverage: NCCN 2018 published by NCCN and Physician Data Query [PDQ 2018] published by the National Cancer Institute (NCI). The NCCN guidelines initially abstracted were those published in August 2018 (i.e., version 2.0). However, an update (version 3.0) became available when finalising the SLR report. The SLR report was updated to replace recommendations from version 2 with those of version 3

- Two guidelines with pan-European coverage: Fey 2013 published by the European Society for Medical Oncology (ESMO) and Döhner 2017 published by ELN

- One guideline for the UK: Milligan 2006 published by the British Society of Haematology (BSH)

- One guideline for Germany: Onkopedia 2018 published by several German and Swiss associations

- $\quad$ One guideline for Japan: Miyawaki 2017 published by the Japanese Society of Haematology (JSH)

- $\quad$ Five guidelines with local coverage: NOSCAN 2017 published by the NOSCAN for North of Scotland and LCA 2015 published by the London Cancer Alliance (LCA) for London, Manchester Cancer 2015 published by Manchester Cancer, NHS Anglia 2013 published by NHS in Anglia and NHS Birmingham 2011 published by NHS Birmingham. Manchester Cancer updated the Clinical Patient Pathway for AML in May 2018 [Manchester Cancer 2018]. However, this update was not deemed relevant as it does not provide any specific recommendations for patients with R/R AML.

The following bodies were searched but no relevant guidelines were identified:

- The British Committee for Standards in Haematology has not published any relevant guidelines

- $\mathrm{ASH}$ has published guidelines for the diagnostic and prognostic evaluation of new AML cases [Arber 2017] but has not developed any guidelines on management of AML. ASH is currently developing new clinical practice guidelines on the management of AML in older adults. Publication of these guidelines is expected in $2020^{\S}$.

- The French Haute Autorité de Sante (HAS) published guidelines in 2011 for treatment of acute leukaemias in the adult [HAS 2011]. However, these guidelines do not provide any recommendations for $\mathrm{R} / \mathrm{R}$ AML (regardless of FLT3 status). These guidelines were updated in 2015, but they do not provide any recommendations for RR AML, either [HAS 2015].

No relevant recent guidelines were identified for either Italy or Spain. The Italian Society of Haematology, Italian Society of Experimental Haematology and Italian Group for Bone Marrow Transplantation published guidelines for the treatment of AML in 2009 [Morra 2009]. The aim of these guidelines was to capture the new therapies available for patients with de novo AML. However, the guidelines do not address R/R AML and do not provide any recommendations for these patients or for patients with FLT3+ AML (treatment naïve or R/R). Thus, Morra 2009 has not been included in this SLR.

All 12 guidelines included in this SLR covered all stages of AML. None of them focused on R/R AML or FLT3+ AML. https://www.guidelinecentral.com/summaries/organizations/britishcommittee-for-standards-in-haematology/?start $=20$. Accessed on December $01,2018$. 
International Journal of Engineering Applied Sciences and Technology, 2020

Vol. 4, Issue 9, ISSN No. 2455-2143, Pages 61-83

Published Online January 2020 in IJEAST (http://www.ijeast.com)

Table 0-1 Treatment guidelines and other publications selected for review

\begin{tabular}{|c|c|c|c|c|}
\hline Reference & $\begin{array}{l}\text { Publishing } \\
\text { association }\end{array}$ & $\begin{array}{l}\text { Geographic } \\
\text { scope }\end{array}$ & Objective of the guidelines & Topic of the guideline \\
\hline $\begin{array}{l}\text { Döhner } \\
2017\end{array}$ & ELN & Europe & $\begin{array}{l}\text { To update the } 1^{\text {st }} \text { edition of the ELN } \\
\text { recommendations for diagnosis and } \\
\text { management of AML in adults, published in } \\
2010\end{array}$ & $\begin{array}{l}\text { AML (de novo, treatment- } \\
\text { naive and } R / R \text { ) }\end{array}$ \\
\hline Fey 2013 & ESMO & Europe & $\begin{array}{l}\text { Not reported but the authors put forward } \\
\text { recommendations for diagnosis and } \\
\text { management of AML }\end{array}$ & $\begin{array}{l}\text { AML (de novo, treatment- } \\
\text { naive and } R / R \text { ) }\end{array}$ \\
\hline LCA 2015 & LCA & London, UK & $\begin{array}{l}\text { Not reported but the authors put forward } \\
\text { recommendations for diagnosis and } \\
\text { management of AML }\end{array}$ & $\begin{array}{l}\text { AML (de novo, treatment- } \\
\text { naive and } R / R \text { ) }\end{array}$ \\
\hline $\begin{array}{l}\text { Mancheste } \\
\text { r Cancer } \\
2015\end{array}$ & $\begin{array}{l}\text { Manchester } \\
\text { Cancer }\end{array}$ & $\begin{array}{l}\text { Manchester, } \\
\text { UK }\end{array}$ & $\begin{array}{l}\text { Not reported but the authors put forward } \\
\text { recommendations for diagnosis and } \\
\text { management of AML }\end{array}$ & $\begin{array}{l}\text { AML (de novo, treatment- } \\
\text { naive and } R / R \text { ) }\end{array}$ \\
\hline $\begin{array}{l}\text { Milligan } \\
2006\end{array}$ & BSH & UK & $\begin{array}{l}\text { Not reported but the authors put forward } \\
\text { recommendations for diagnosis and } \\
\text { management of AML in adults }\end{array}$ & $\begin{array}{l}\text { AML (de novo, treatment- } \\
\text { naive and } R / R \text { ) }\end{array}$ \\
\hline $\begin{array}{l}\text { Miyawaki } \\
2017\end{array}$ & JSH & Japan & $\begin{array}{l}\text { To update the previous JSH guidelines from } \\
2010\end{array}$ & $\begin{array}{l}\text { AML (de novo, treatment- } \\
\text { naive and } R / R \text { ) }\end{array}$ \\
\hline $\begin{array}{l}\text { NCCN } \\
2018\end{array}$ & $\mathrm{NCCN}$ & US & $\begin{array}{l}\text { Not reported but the authors put forward } \\
\text { recommendations for diagnosis and } \\
\text { management of AML }\end{array}$ & $\begin{array}{l}\text { AML (de novo, treatment- } \\
\text { naive and } R / R \text { ) }\end{array}$ \\
\hline $\begin{array}{l}\text { NHS } \\
\text { Anglia } \\
2013\end{array}$ & $\begin{array}{l}\text { NHS } \\
\text { Anglia }\end{array}$ & Anglia, UK & $\begin{array}{l}\text { Not reported but the authors put forward } \\
\text { recommendations for diagnosis and } \\
\text { management of AML }\end{array}$ & $\begin{array}{l}\text { AML (de novo, treatment- } \\
\text { naive and } R / R \text { ) }\end{array}$ \\
\hline $\begin{array}{l}\text { NHS } \\
\text { Birmingha } \\
\text { m } 2011\end{array}$ & $\begin{array}{l}\text { NHS } \\
\text { Birmingha } \\
\text { m }\end{array}$ & $\begin{array}{l}\text { Birmingham, } \\
\text { UK }\end{array}$ & $\begin{array}{l}\text { Not reported but the authors put forward } \\
\text { recommendations for diagnosis and } \\
\text { management of AML }\end{array}$ & $\begin{array}{l}\text { AML (de novo, treatment- } \\
\text { naive and } R / R \text { ) }\end{array}$ \\
\hline $\begin{array}{l}\text { NOSCAN } \\
2017\end{array}$ & NOSCAN & $\begin{array}{l}\text { North } \\
\text { Scotland }\end{array}$ & $\begin{array}{l}\text { Not reported but the authors put forward } \\
\text { recommendations for diagnosis and } \\
\text { management of AML }\end{array}$ & $\begin{array}{l}\text { AML (de novo, treatment- } \\
\text { naive and } R / R \text { ) }\end{array}$ \\
\hline $\begin{array}{l}\text { Onkopedia } \\
2018\end{array}$ & $\begin{array}{l}\text { DGHO, } \\
\text { OeGHO, } \\
\text { SSMO/SS } \\
\text { OM/ } \\
\text { SGMO, } \\
\text { SGH-SSH, } \\
\text { GPOH }\end{array}$ & Germany & $\begin{array}{l}\text { Not reported but the authors put forward } \\
\text { recommendations for diagnosis and } \\
\text { management of AML }\end{array}$ & $\begin{array}{l}\text { AML (de novo, treatment- } \\
\text { naive and } R / R \text { ) }\end{array}$ \\
\hline PDQ 2018 & $\mathrm{NCI}$ & US & $\begin{array}{l}\text { Resource to inform and assist clinicians } \\
\text { who care for cancer patients. It did not } \\
\text { provide formal guidelines or } \\
\text { recommendations for making health care } \\
\text { decisions }\end{array}$ & $\begin{array}{l}\text { AML (de novo, treatment- } \\
\text { naive and } R / R \text { ) }\end{array}$ \\
\hline
\end{tabular}

Abbreviations: AML: acute myeloid leukaemia; BSH: British Society for Haematology; DGHO: German Society of Haematology and Medical Oncology; ELN: European LeukemiaNet; ESMO: European Society for Medical Oncology; GPOH: Society for Paediatric Haematology/Oncology; JSH: Japanese Society of Haematology; LCA: London Cancer Alliance; NCCN: National Comprehensive Cancer Network; NCI: National Cancer Institute; NHS: National Health Service; NOSCAN: North of Scotland Cancer Network; OeGHO: Austrian Society for Haematology \& Medical Oncology; R/R: relapsed / refractory; SGH-SSH: Swiss Society for Haematology; SSMO/SSOM/SGMO: Swiss Society of Medical Oncology; UK: United Kingdom; US: United States. 
International Journal of Engineering Applied Sciences and Technology, 2020

Vol. 4, Issue 9, ISSN No. 2455-2143, Pages 61-83

Published Online January 2020 in IJEAST (http://www.ijeast.com)

\subsubsection{What is the current management of R/R AML?}

Table 0-2. Specific recommendations for patients with FLT3+ R/R AML are discussed in
Recommendations for the management of $\mathrm{R} / \mathrm{R}$ AML are summarised in 


\section{International Journal of Engineering Applied Sciences and Technology, 2020 \\ Vol. 4, Issue 9, ISSN No. 2455-2143, Pages 61-83 \\ Published Online January 2020 in IJEAST (http://www.ijeast.com)}

Table 0-1.

All guidelines provide similar recommendations regarding therapeutic options for R/R AML:

- Salvage therapy

- Offering participation in a clinical trial with new interventions

- $\quad$ Bone marrow transplantation (BMT).

Both NCCN [NCCN 2018] and ELN [Döhner 2017] guidelines recommend participation in a clinical trial as the best therapeutic option for patients with R/R AML. NCCN guidelines highlight that there are several clinical trials investigating targeted therapies for patients with $R / R$ AML. However, they also recommend gilteritinib [Category 2A] as a therapeutic option for patients with FLT3+ R/R AML.

All guidelines highlight the lack of evidence that would allow to prioritise one therapeutic option over the other ones for patients with R/R AML. However, the Japanese guidelines highlight that salvage therapy alone cannot cure these patients and therefore, patients with R/R AML are candidates for HSCT [Miyawaki 2017].

NCCN 2018 recommend conducting molecular profiling including FLT3 mutations to guide selection of therapy. NCCN 2018 recommend taking into account the patient's age and time between remission and relapse. For patients younger than 60 years of age, the options include clinical trial [strongly preferred] and chemotherapy followed by matched sibling or alternative donor HSCT. If the relapse occurs at or after 12 months since remission, NCCN guidelines recommend repeating the initial successful induction regimen. For patients $\geq 60$ years of age, options include participating in a clinical trial [strongly preferred], best supportive care and chemotherapy followed by matched sibling or alternative donor HSCT. Again, if the relapse occurs at or after 12 months since remission, NCCN guidelines recommend repeating the initial successful induction regimen.

Re-challenge with the same regimen used for the initial remission induction is also recommended in the ESMO [Fey 2013] and JSH [Miyawaki 2017] guidelines if relapse occurs at a late stage. 
Table 0-2 Key recommendations for management of R/R AML

\begin{tabular}{|c|c|c|}
\hline Reference & Association & Recommendation for R/R AML \\
\hline \multicolumn{3}{|l|}{ US } \\
\hline NCCN 2018 & $\mathrm{NCCN}$ & $\begin{array}{l}\text { - Molecular profiling including FLT3 mutations is recommended to guide selection of } \\
\text { therapy } \\
\text { - Treatment strategies for relapse are categorised according to patient age and time of } \\
\text { relapse } \\
\text { - For patients }<60 \text { years if relapse is early (within first } 12 \text { months) } \\
\circ \quad \text { Clinical trial [strongly preferred] OR } \\
\circ \text { Chemotherapy followed by matched sibling or alternative donor HSCT } \\
\text { - For patients }<60 \text { years if relapse is late ( } \geq 12 \text { months) } \\
\circ \quad \text { Clinical trial [strongly preferred] OR } \\
\circ \quad \text { Chemotherapy followed by matched sibling or alternative donor HSCT } \\
\circ \quad \text { Repeat initial successful induction regimen } \\
\text { - For patients } \geq 60 \text { and early relapse } \\
\circ \quad \text { Clinical trial [strongly preferred] OR } \\
\circ \text { Best supportive care OR } \\
\circ \text { Chemotherapy followed by matched sibling or alternative donor HSCT } \\
\text { - For patients } \geq 60 \text { and late relapse } \\
\circ \text { Clinical trial [strongly preferred] OR } \\
\circ \text { Repeat initial successful induction regimen OR } \\
\circ \text { Best supportive care OR } \\
\circ \text { Chemotherapy followed by matched sibling or alternative donor HSCT }\end{array}$ \\
\hline PDQ 2018 & NCI & $\begin{array}{l}\text { - No standard regimen exists for the treatment of patients with relapsed AML, particularly } \\
\text { in patients with a first remission duration of less than } 1 \text { year } \\
\text { - Potential therapies include salvage therapy, clinical trial with new interventions and } \\
\text { bone marrow therapy }\end{array}$ \\
\hline \multicolumn{3}{|l|}{ Europe } \\
\hline Fey 2013 & ESMO & $\begin{array}{l}\text { - Patients failing to respond to one or two cycles of induction treatment are considered } \\
\text { refractory and are at very high risk of ultimate treatment failure } \\
\text { - Carefully selected patients with an HLA matched donor may be offered allo-HSCT, } \\
\text { albeit with limited chances of success and at the cost of considerable morbidity from this } \\
\text { procedure [II, B] } \\
\text { - For patients unsuited to this approach, BSC or palliative systemic treatment is often a } \\
\text { reasonable option with, at least, limited toxic effect. The prognosis of such patients is } \\
\text { often dismal regardless of treatment attempts } \\
\text { - Patients presenting with relapse after a first remission may be offered intensive re- } \\
\text { induction, for which chances of success are better after longer duration of first remission } \\
\text { - Patients in second or subsequent remission may still qualify for allo-HSCT with a family } \\
\text { or unrelated HLA-matched donor, or with cord blood-derived stem cells }\end{array}$ \\
\hline Döhner 2017 & ELN & $\begin{array}{l}\text { - Treatment of patients with relapsed or primary refractory disease requires a balanced } \\
\text { assessment of the likely benefit of further therapy vs the potential complications } \\
\text { associated with salvage chemotherapy } \\
\text { - Enrolment in a clinical trial should be the priority whenever possible } \\
\text { - No specific salvage regimen has emerged as the standard for treating primary refractory } \\
\text { or relapsed AML. Salvage regimens are the same as those regimens used for remission } \\
\text { induction } \\
\text { - Selection of salvage regimen depends on eligibility for intensive chemotherapy }\end{array}$ \\
\hline Sec & & \\
\hline
\end{tabular}




\begin{tabular}{|c|c|c|}
\hline Reference & Association & Recommendation for $\mathrm{R} / \mathrm{R}$ AML \\
\hline $\begin{array}{l}\text { NOSCAN } \\
2017\end{array}$ & NOSCAN & $\begin{array}{l}\text { - Guidelines are based on Szer } 2012 \\
\text { - There are limited data to recommend an optimal salvage regimen } \\
\text { - For patients with relapsed non-APL AML, consider relevant prognostic factors before } \\
\text { attempting salvage therapy in this setting including patient age, duration of remission, } \\
\text { co-morbidity and cytogenetics at original presentation and relapse } \\
\text { - There are limited data to guide the choice of salvage chemotherapy prior to allo-BMT in } \\
\text { eligible patients but consider FLAG or FLAG-IDA in patients whose duration of } \\
\text { remission is less than } 2 \text { years. These patients deemed suitable for intensive salvage } \\
\text { therapy should be discussed with the transplantation team at the time of relapse } \\
\text { - Molecular MiRD monitoring may be useful to guide the need for additional } \\
\text { consolidation with HSCT in eligible patients } \\
\text { - Follow Up } \\
\text { On neutrophil recovery after each cycle of chemotherapy, stop prophylactic } \\
\text { medication unless previous fludarabine. In this circumstance it would appear } \\
\text { reasonable to continue PCP prophylaxis for } 6 \text { months after last exposure to } \\
\text { fludarabine } \\
\text { Consider venesection programme after } 4-6 \text { months if Hb in normal range, and if } \\
\text { pt treated with curative intent and if ferritin >1000 and/or transferrin Saturation > } \\
50 \% \text { or ferritin >1000 and deranged LFTs } \\
\text { In younger patients, particularly women, an echocardiogram for assessment of } \\
\text { cardiac function should be considered. This will be particularly important in the } \\
\text { event of pregnancy. Consider referral to late effects clinic (if available) from } 4 \\
\text { years post therapy }\end{array}$ \\
\hline \multicolumn{3}{|l|}{ Germany } \\
\hline $\begin{array}{l}\text { Onkopedia } \\
2018\end{array}$ & $\begin{array}{l}\text { DGHO, } \\
\text { OeGHO, } \\
\text { SSMO/SSOM/ } \\
\text { SGMO, SGH- } \\
\text { SSH, GPOH }\end{array}$ & $\begin{array}{l}\text { - There are no prospective, controlled studies that allow to determine whether a treatment } \\
\text { strategy is superior to another one in R/R AML. Therapeutic options include: salvage } \\
\text { therapy, clinical trial with experimental therapies, and BSC } \\
\text { - There is general consensus for reinduction therapy with intermediate or high dose AraC } \\
\text { - For consolidation, allo-HSCT is the treatment of choice. If an HLA-identical family } \\
\text { donor or a third-party donor are not available, stem cell sources such as umbilical cord } \\
\text { blood or HLA haploidentical transplants of family donors may be used } \\
\text { - If not eligible for intensive salvage therapy, HMA should be considered }\end{array}$ \\
\hline \multicolumn{3}{|l|}{ UK } \\
\hline LCA 2015 & LCA & $\begin{array}{l}\text { - All suitable patients should be discussed with the transplant team to consider HSCT. } \\
\text { Patients without an HSCT option should be offered a clinical trial for novel agents, if } \\
\text { available } \\
\text { Primary refractory AML } \\
\text { - A lack of response, or only PR, to induction chemotherapy is associated with a poor } \\
\text { prognosis in general. The general approach is to escalate to } 1-2 \text { cycles of FLAG-(IDA) } \\
\text { chemotherapy in an attempt to gain CR prior to a potential allo-HSCT if a suitable donor } \\
\text { is identified. Alternative salvage regimens pre-allograft are offered in the treatment } \\
\text { algorithm } \\
\text { Relapsed AML } \\
\text { - The management of patients who relapse is complex and often the outcome is } \\
\text { unsatisfactory. In deciding upon the most appropriate salvage therapy, many factors } \\
\text { need to be taken into consideration, including induction protocols used, the patient's } \\
\text { age, performance status, cytogenetics, the length of initial CR achieved and the potential } \\
\text { for consolidation with an allo-HSCT (or indeed second HSCT and/or DLI therapy). In } \\
\text { younger and/or more fit patients, treatment is planned with a view to proceeding to an } \\
\text { HSCT }\end{array}$ \\
\hline
\end{tabular}




\section{International Journal of Engineering Applied Sciences and Technology, 2020 \\ Vol. 4, Issue 9, ISSN No. 2455-2143, Pages 61-83 \\ Published Online January 2020 in IJEAST (http://www.ijeast.com)}

\begin{tabular}{|c|c|c|}
\hline Reference & Association & Recommendation for R/R AML \\
\hline $\begin{array}{l}\text { Manchester } \\
\text { Cancer } 2015\end{array}$ & $\begin{array}{l}\text { Manchester } \\
\text { Cancer }\end{array}$ & $\begin{array}{l}\text { Molecular FLT3 testing should be conducted as part of the initial AML diagnosis } \\
\text { Allo-HSCT offers the best prospect of a cure for patients in 2nd or higher remission } \\
\text { Refractory AML: } \\
\text { - Salvage chemotherapy or allo-HSCT } \\
\text { - Patients who are not suitable for allo-HSCT should be considered for investigational } \\
\text { therapy of novel agents } \\
\text { Relapsed AML: } \\
\text { - If CR duration < } 6 \text { months, palliative care or experimental therapy } \\
\text { - If CR duration > } 6 \text { months, consider salvage chemotherapy and HSCT } \\
\text { - Patients who achieve CR should receive allo-HSCT }\end{array}$ \\
\hline Milligan 2006 & $\mathrm{BSH}$ & $\begin{array}{l}\text { - Patients with relapsed disease should be stratified according to cytogenetics, age and } \\
\text { length of CR1 to identify the best salvage approach } \\
\text { - No clear evidence for the benefit of HSCT as part of salvage therapy in R/R AML }\end{array}$ \\
\hline $\begin{array}{l}\text { NHS Anglia } \\
2013\end{array}$ & NHS Anglia & $\begin{array}{l}\text { - If eligible for induction therapy, patients should be offered participation in a clinical trial } \\
\text { - If not in trial, then a high dose cytarabine regimen or BSC } \\
\text { - If CR after salvage therapy, HSCT should be offered }\end{array}$ \\
\hline $\begin{array}{l}\text { NHS } \\
\text { Birmingham } \\
2011\end{array}$ & $\begin{array}{l}\text { NHS } \\
\text { Birmingham }\end{array}$ & $\begin{array}{l}\text { - Molecular FLT3 testing should be conducted as part of the initial AML diagnosis } \\
\text { - Salvage chemotherapy to achieve CR } 2 \text { should be considered if the patient has an HSCT } \\
\text { option available and is in good performance status }\end{array}$ \\
\hline \multicolumn{3}{|l|}{ Japan } \\
\hline $\begin{array}{l}\text { Miyawaki } \\
2017\end{array}$ & & $\begin{array}{l}\text { - Patients who do not respond to induction therapy and who relapse after achieving CR } \\
\text { require salvage therapy for R/R AML. However, as R/R AML is unlikely to be cured } \\
\text { with chemotherapy alone, these patients are candidates for allo-HSCT } \\
\text { - There is no evidence indicating whether the same induction therapy regimen should be } \\
\text { repeated, or the regimen should be changed. However, it is reasonable to repeat the same } \\
\text { induction therapy regimen because it may be possible to achieve remission at a certain } \\
\text { frequency [Category 2B] } \\
\text { - No specific index for determining eligibility for HSCT in patients with AML not in } \\
\text { remission has been established. At present, it is recommended to determine eligibility } \\
\text { for HSCT by comprehensively considering prognostic factors based on retrospective } \\
\text { analysis and HSCT-related factors (e.g., donor source) and engaging in shared decision- } \\
\text { making with the patient. There is no established index for predicting which of the } \\
\text { patients with AML not in remission will benefit from receiving chemotherapy before } \\
\text { HSCT [Category } 3 \text { ] } \\
\text { - Induction or post-remission therapy with G-CSF for AML can shorten the duration of } \\
\text { neutropenia and improve quality of life during this phase. It may be considered for } \\
\text { elderly patients and patients with severe concomitant infections [Category } 2 \mathrm{~B} \text { (induction } \\
\text { therapy), Category } 2 \mathrm{~A} \text { (post-remission therapy)] }\end{array}$ \\
\hline
\end{tabular}

Abbreviations: allo-BMT: allogeneic bone marrow transplantation; allo-HSCT: allogeneic haematopoietic stem cell transplantation; AML: acute myeloid leukaemia; APL: acute promyelocytic leukaemia; BSC: best supportive care; BSH: British Society for Haematology; CR: complete remission; CR1: first complete remission; CR2: second complete remission; DGHO: German Society of Haematology and Medical Oncology; DLI: donor lymphocyte infusions; ELN: European LeukemiaNet; ESMO: European Society for Medical Oncology; FLAG: fludarabine, cytarabine and granulocyte colony stimulating factor; FLAG-IDA: fludarabine, cytarabine and G-CSF plus idarubicin; FLT3: FMS-like tyrosine kinase 3; G-CSF: granulocyte colony stimulating factor; GPOH: Society for Paediatric Haematology/Oncology; Hb: haemoglobin; HLA: human leukocyte antigen; HMA: hypomethylating agents; HSCT: haematopoietic stem cell transplantation; LCA: London Cancer Alliance; LFT: liver function tests; MiRD: minimal residual disease; NCCN: National Comprehensive Cancer Network; NCI: National Cancer Institute; NHS: National Health Service; NOSCAN: North of Scotland Cancer Network; OeGHO: Austrian Society for Haematology \& Medical Oncology; PCP: primary care physician; PDQ: Physician Data Query; PR: partial response; pt: patient; R/R: relapsed or refractory; SGH-SSH: Swiss Society for Haematology; SSMO/SSOM/SGMO: Swiss Society of Medical Oncology; UK: United Kingdom; US: United States. 


\subsubsection{Recommended salvage therapy for $R / R A M L$}

An overview of the specific therapies recommended as salvage therapy in the selected guidelines is provided in

Table 0-3.

ESMO guidelines [Fey 2013] recommend either best supportive care or palliative chemotherapy. However, they do not specify which palliative chemotherapy should be given.

The ELN guidelines recommend the "7 +3 " induction therapy to all patients who are eligible for intensive chemotherapy [Döhner 2017]. This regimen consists of 3 days of an intravenous (IV) anthracycline (daunorubicin at least 60 $\mathrm{mg} / \mathrm{m}^{2}$, idarubicin $12 \mathrm{mg} / \mathrm{m}^{2}$, or mitoxantrone $12 \mathrm{mg} / \mathrm{m}^{2}$ ), and 7 days of continuous infusion cytarabine $\left(100-200 \mathrm{mg} / \mathrm{m}^{2}\right)$. For those patients who are not candidates for intensive chemotherapy, treatment options include: azacitidine, decitabine or low-dose cytarabine (not recommended in patients with adverse-risk genetics) until progression, or BSC Including hydroxyurea for patients who cannot tolerate any antileukaemic therapy, or who do not wish any therapy [Döhner 2017]. Common salvage regimens for patients refractory to a first induction cycle or with relapsed disease include IDAC with or without daunorubicin, idarubicin or mitoxantrone if candidates for intensive therapy [Döhner 2017].

NOSCAN 2017 recommend FLAG or FLAG-IDA prior to allo-BMT in eligible patients if duration of remission is less than 2 years.

German guidelines [Onkopedia 2018] recommend intermediate or high dose cytarabine if eligible for salvage therapy. If not eligible for intensive salvage therapy, hypomethylating agents (HMAs) should be considered.

The LCA guidelines [LCA 2015] recommend allograft after second induction or first consolidation, or re-induction with FLAG with or without idarubicin, high-dose cytarabine (HiDAC), CIA (clofarabine, idarubicin, and cytarabine), D-Clo (daunorubicin and clofarabine), CLAG \pm IDA (cladribine, cytarabine, mitoxantrone, and G-CSF with or without idarubicin), or MEC. Both Manchester Cancer 2015 and NHS Birmingham 2011 base their recommendations on duration of CR. If duration is longer than 12 months, then reinduction with the same regimen used in the initial induction should be offered. If duration is shorter than 6 months, Manchester Cancer 2015 recommend palliative care or experimental therapy. If duration is longer than 6 months, they both recommend HiDAC-based regimens. BSH guidelines [Milligan 2006] recommend cytarabine at low (100$\left.200 \mathrm{mg} / \mathrm{m}^{2}\right)$, intermediate $\left(1 \mathrm{~g} / \mathrm{m}^{2}\right)$ or high doses $\left(2-3 \mathrm{~g} / \mathrm{m}^{2}\right)$, in combination with other drugs. The guidelines also highlight that in the elderly, gemtuzumab has shown promise as a salvage agent in patients with relapsed disease and could be preferable to further intensive chemotherapy in this setting (grade B recommendation, level IIb evidence). NHS Anglia 2013 recommend participation in a clinical trial if the patient is eligible for induction therapy. If the patient is not in a trial, then a HiDACbased regimen (e.g. FLAG) or supportive care should be offered.

The JSH guidelines [Miyawaki 2017] provide different recommendations based on the age of patients. In younger patients with AML, if remission is not achieved with the first cycle of induction therapy, they recommend to repeat the same regimen as for induction therapy. In addition, salvage therapy with HiDAC or IDAC should be performed if remission is still not achieved after the second cycle. In elderly patients with AML, treatment depends on the patient's Eastern Cooperative Oncology Group (ECOG) performance status (PS) and comorbidities. AlloHSCT is the preferred option in patients with ECOG 0 or 1, regardless of risk status. Otherwise, salvage chemotherapy with low-dose cytarabine or participation in a clinical trial should be offered. If the patient has serious comorbidities, BSC alone should be offered regardless of ECOG PS. If the patient has $\mathrm{ECOG} \geq 2$, BSC is the only option [Miyawaki 2017].

NCCN guidelines recommend different aggressive and less aggressive salvage regimens. In addition, they also provide specific recommendations for patients depending on molecular mutations. For patients with FLT3+ R/R AML, gilteritinib (category 2A) is recommended and if FLT3-ITD+, then hypomethylating agents (5-azacitidine or decitabine) plus sorafenib (category 2A) should be offered. If patients have AML with IDH2 mutations, enasidenib (category 2A) is recommended while ivosidenib (category 2A) is recommended for patients with IDH1+ AML, and gemtuzumab (category 2A) for patients with CD33+ AML [NCCN 2018].

In the ELN guidelines, consolidation therapy after induction for patients aged 18 to 60/65 years of age is based on the patient's risk status. For patients with favourable-risk genetics, 2 to 4 cycles of IDAC is recommended. For patients with intermediaterisk genetics, consolidation therapy consisting of allo-HSCT from matched-related or unrelated donor, 2-4 cycles of IDAC, or high-dose therapy and auto-HSCT are recommended treatment options. For patients with adverse-risk genetics, allo-HSCT from matched-related or unrelated donor is the recommended consolidation therapy. Consolidation therapy for patients older than 60/65 years of age also depends on the risk classification. For patients with favourable-risk genetics, consolidation consists of 2 to 3 cycles of IDAC. For patients with intermediate/adverserisk genetics, the benefit of intensive consolidation therapy has not been stablished. For these patients, an allo-HSCT (in patients with low HSCT-Comorbidity Index score), or investigational therapy should be considered [Döhner 2017].

The LCA guidelines recommend BSC with or without cytoreductive chemotherapy (hydroxyurea, etoposide, mitoxantrone, or cytarabine [subcutaneously or continuous infusion]), a combination of amsacrine, cytarabine, and etoposide, or EZ (etoposide) if the patient is not eligible to HSCT or fails to respond to re-induction therapy [LCA 2015]. 
Table 0-3 Key recommendations for salvage therapy for R/R AML

\begin{tabular}{|c|c|c|}
\hline Reference & Association & Recommendation for R/R AML \\
\hline \multicolumn{3}{|l|}{ US } \\
\hline NCCN 2018 & $\mathrm{NCCN}$ & 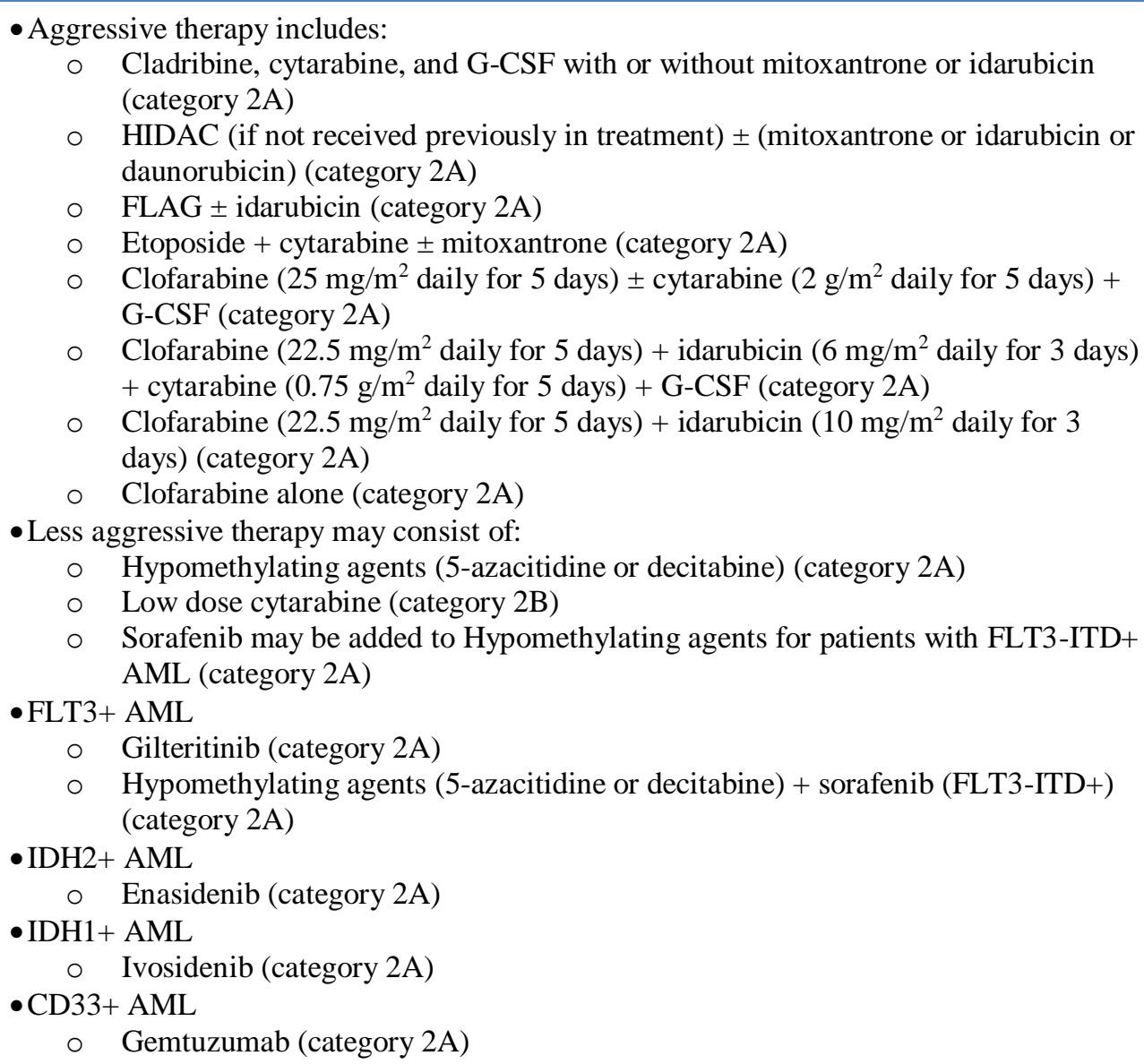 \\
\hline PDQ 2018 & NCI & $\begin{array}{l}\text { Potential therapies: } \\
\text { - Mitoxantrone + cytarabine } \\
\text { - Idarubicin + cytarabine or high-dose etoposide and cyclophosphamide } \\
\text { - MEC [Level of evidence: 3iiiDiv] } \\
\text { - MEC with or without PSC388 [Level of evidence: 1iiDiv] } \\
\text { - Treatments with new agents under clinical evaluation remain appropriate in eligible } \\
\text { patients with recurrent AML } \\
\text { - Gemtuzumab in relapsed AML expressing CD33 } \\
\text { - Clofarabine in first relapse as a single agent or in combination with intermediate-dose } \\
\text { cytarabine [Level of evidence: 3iiiDiv] } \\
\text { - BMT [Level of evidence: 3iDii] } \\
\text { O HLA-matched sibling HSCT [Level of evidence: 3iDii] } \\
\text { Allo-BMT from an HLA-matched donor in early first relapse or in second CR } \\
\text { [Level of evidence: 3iiiA] }\end{array}$ \\
\hline
\end{tabular}


International Journal of Engineering Applied Sciences and Technology, 2020

Vol. 4, Issue 9, ISSN No. 2455-2143, Pages 61-83

Published Online January 2020 in IJEAST (http://www.ijeast.com)

\begin{tabular}{|c|c|cc|}
\hline Reference & Association & $\circ \begin{array}{l}\text { Recommendation for R/R AML } \\
\text { lymphocytes from the donor [Level of evidence: 3iiiA] }\end{array}$ \\
\hline
\end{tabular}




\begin{tabular}{|c|c|c|}
\hline Reference & Association & Recommendation for R/R AML \\
\hline \multicolumn{3}{|l|}{ Europe } \\
\hline Fey 2013 & ESMO & $\begin{array}{l}\text { - Carefully selected patients with an HLA matched donor may be offered allo-HSCT, } \\
\text { albeit with limited chances of success and at the cost of considerable morbidity from } \\
\text { this procedure [II, B] } \\
\text { - For patients unsuited to this approach, BSC or palliative systemic treatment is often a } \\
\text { reasonable option with, at least, limited toxic effect }\end{array}$ \\
\hline Döhner 2017 & ELN & 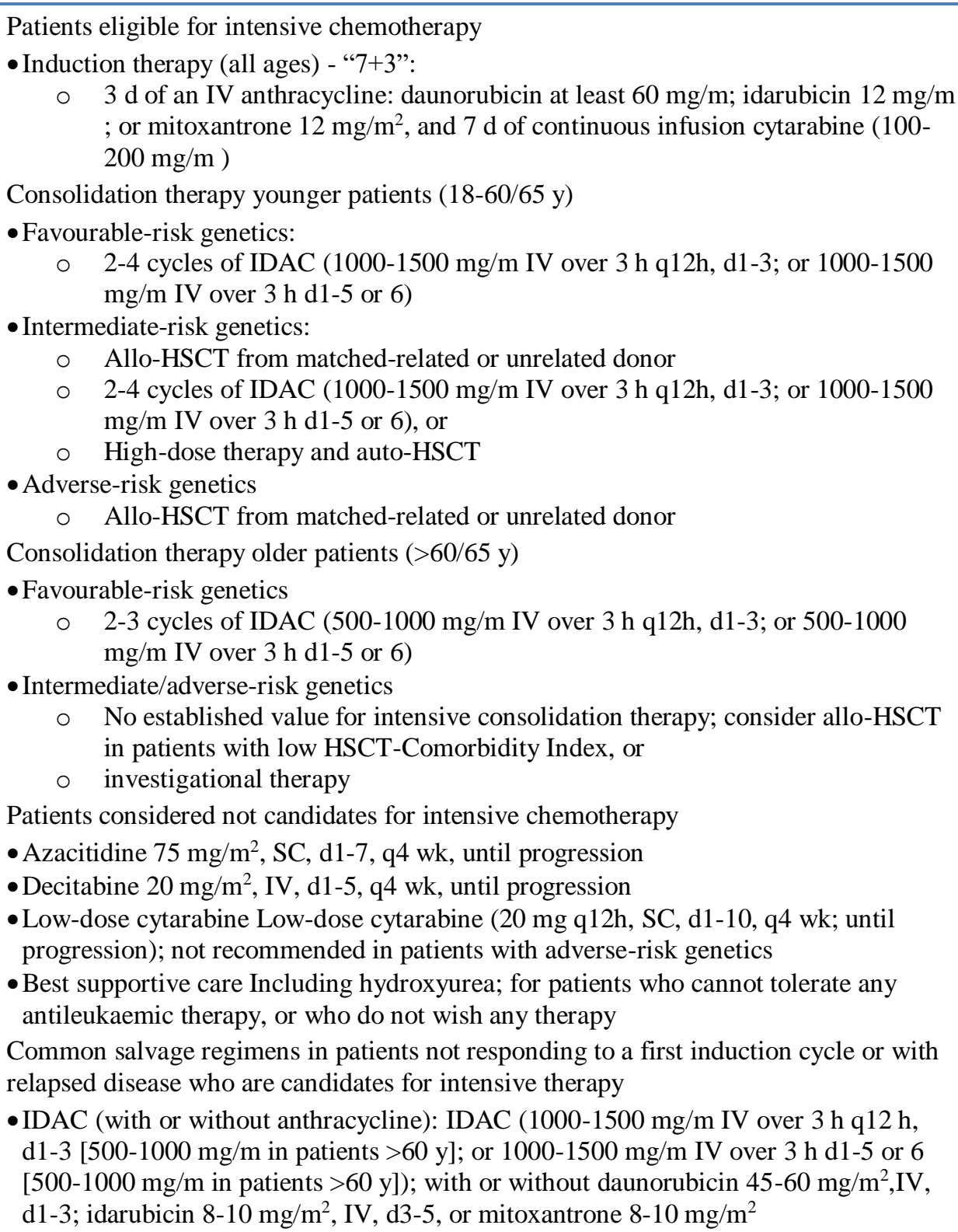 \\
\hline \multicolumn{3}{|l|}{ Scotland } \\
\hline NOSCAN 2017 & NOSCAN & $\begin{array}{l}\text { The only salvage therapy mentioned in the NOSCAN guidelines is: } \\
\text { - FLAG or FLAG-IDA prior to allo-BMT in eligible patients if duration of remission is } \\
\text { less than } 2 \text { years }\end{array}$ \\
\hline \multicolumn{3}{|l|}{ Germany } \\
\hline
\end{tabular}




\begin{tabular}{|c|c|c|}
\hline Reference & Association & Recommendation for $\mathbf{R} / \mathbf{R} A M L$ \\
\hline $\begin{array}{l}\text { Onkopedia } \\
2018\end{array}$ & $\begin{array}{l}\text { DGHO, OeGHO, } \\
\text { SSMO/SSOM/ } \\
\text { SGMO, SGH- } \\
\text { SSH, GPOH }\end{array}$ & $\begin{array}{l}\text { - Intermediate or high dose AraC if eligible for salvage therapy } \\
\text { - If not eligible for intensive salvage therapy, HMA should be considered }\end{array}$ \\
\hline \multicolumn{3}{|l|}{ UK } \\
\hline LCA 2015 & LCA & $\begin{array}{l}\text { If refractory and fit for re-induction } \\
\text { - HLA type siblings and discuss with transplant centre } \\
\circ \text { Consider allograft after 2nd induction or 1st consolidation OR } \\
\circ \text { Re-induction with FLAG } \pm \text { IDA, HiDAC, CIA, D-Clo, CLAG } \pm \text { IDA, MEC } \\
\text {-If failure to the above: } \\
\circ \text { Supportive care } \pm \text { cytoreductive chemotherapy (hydroxyurea, etoposide, } \\
\text { mitoxantrone or AraC (subcutaneously of continuous infusion), a combination } \\
\text { of amsacrine, cytarabine and etoposide, or EZ }\end{array}$ \\
\hline $\begin{array}{l}\text { Manchester } \\
\text { Cancer } 2015\end{array}$ & $\begin{array}{l}\text { Manchester } \\
\text { Cancer }\end{array}$ & $\begin{array}{l}\text { Failure to respond to the first cycle of induction therapy is a major predictor of a poor } \\
\text { outcome and conventional chemotherapy then offers virtually no prospect of long term } \\
\text { DFS. } \\
\text { Several salvage regimens have been assessed (e.g., FLAG-IDA) and can be given if } \\
\text { there is potential for an allo-HSCT } \\
\text { - If CR duration }<6 \text { months: palliative care or experimental therapy } \\
\text { - If CR duration >6months: high dose AraC based salvage chemotherapy (e.g. FLAG or } \\
\text { FLAG-IDA) } \\
\text { - If CR duration >1 year, reinduction therapy with initial induction therapy }\end{array}$ \\
\hline Milligan 2006 & $\mathrm{BSH}$ & $\begin{array}{l}\text { - Mainstay: cytarabine at low }\left(100-200 \mathrm{mg} / \mathrm{m}^{2}\right) \text {, intermediate }\left(1 \mathrm{~g} / \mathrm{m}^{2}\right) \text { or high doses } \\
\left(2-3 \mathrm{~g} / \mathrm{m}^{2}\right) \text {, in combination with other drugs. } \\
\text { - HSCT using a myeloablative conditioning regimen. } \\
\text { - In the elderly, GO shows promise as a salvage agent in patients with relapsed disease, } \\
\text { and may be preferable to further intensive chemotherapy in this setting (grade B } \\
\text { recommendation, level IIb evidence). }\end{array}$ \\
\hline $\begin{array}{l}\text { NHS Anglia } \\
2013\end{array}$ & NHS Anglia & $\begin{array}{l}\text { - If eligible for induction therapy, patients should be offered participation in a clinical } \\
\text { trial } \\
\text { - If not in trial, then a high dose cytarabine regimen (e.g. FLAG) or supportive care }\end{array}$ \\
\hline $\begin{array}{l}\text { NHS } \\
\text { Birmingham } \\
2011\end{array}$ & $\begin{array}{l}\text { NHS } \\
\text { Birmingham }\end{array}$ & $\begin{array}{l}\text { - Intensive salvage with high dose cytarabine } \\
\text { If } \mathrm{CR}>12 \text { months: reinduction with previous induction regimen }\end{array}$ \\
\hline \multicolumn{3}{|l|}{ Japan } \\
\hline Miyawaki 2017 & JSH & $\begin{array}{l}\text { In younger patients with AML: } \\
\text { - When remission is not achieved with the first cycle of induction therapy, it is common } \\
\text { to repeat the same regimen as for induction therapy } \\
\text { - Salvage therapy containing high-dose or intermediate-dose cytarabine is then } \\
\text { performed if remission is still not achieved after the second cycle } \\
\text { Good-risk group: high dose cytarabine }\left(2 \mathrm{~g} / \mathrm{m}^{2} / 12 \mathrm{hr}\right) \times 5 \text { days } \geq 3 \text { cycles } \\
\text { Intermediate- and poor-risk groups: } \\
\text { If allogeneic donor is available: allo-HSCT (related or unrelated donor) } \\
\text { If allogeneic donor is not available: consolidation therapy containing non- } \\
\text { cross-resistant agents, } 4 \text { cycles } \\
\text { In elderly patients with AML } \\
\text { Treatment will depend on the ECOG PS and comorbidities. } \\
\text { - If serious comorbidities, and regardless of ECOG PS: }\end{array}$ \\
\hline
\end{tabular}


International Journal of Engineering Applied Sciences and Technology, 2020

Vol. 4, Issue 9, ISSN No. 2455-2143, Pages 61-83

Published Online January 2020 in IJEAST (http://www.ijeast.com)

\begin{tabular}{|c|c|c|}
\hline Reference & Association & Recommendation for $\mathrm{R} / \mathrm{R}$ AML \\
\hline & & $\begin{array}{l}\text { BSC } \\
\text { - If ECOG } 0-1 \text { and good/intermediate risk } \\
\circ \quad \text { If patient wants a HSCT, allo-HSCT is the preferred option } \\
\circ \text { If patient does not wish a HSCT: salvage chemotherapy which should be: } \\
\text { - Daunorubicin }\left(40 \mathrm{mg} / \mathrm{m}^{2}\right) \times 3 \text { days + enocitabine }\left(200 \mathrm{mg} / \mathrm{m}^{2}\right) \times 8 \text { days or } \\
\text { - Daunorubicin }\left(40 \mathrm{mg} / \mathrm{m}^{2}\right) \times 3 \text { days }+ \text { cytarabine }\left(100 \mathrm{mg} / \mathrm{m}^{2}\right) \times 7 \text { days or } \\
\text { - If ECOG } 0-1 \text { and poor risk } \\
\circ \quad \text { If patient wants a HSCT, allo-HSCT is the preferred option } \\
\circ \quad \text { If patient does not wish a HSCT: salvage chemotherapy which should be: } \\
\text { - Low-dose cytarabine or } \\
\text { - Clinical trial } \\
\text { ECOG } \geq 2 \\
\text { BSC }\end{array}$ \\
\hline
\end{tabular}

Abbreviations: allo-BMT: allogeneic bone marrow transplantation; allo-HSCT: allogeneic haematopoietic stem cell transplantation; AML: acute myeloid leukaemia; AraC: cytarabine; auto-HSCT: autologous haematopoietic stem cell transplantation; BMT: bone marrow transplantation; BSC: best supportive care; BSH: British Society for Haematology; CD33+: CD33 mutation positive; CIA: clofarabine, idarubicin, and cytarabine; CLAG \pm IDA: cladribine, cytarabine, mitoxantrone, and granulocyte colony stimulating factor with or without idarubicin; CR: complete remission; d1-5: day 1 to 5; D-Clo: daunorubicin and clofarabine; DFS: disease-free survival; DGHO: German Society of Haematology and Medical Oncology; ECOG: Eastern Cooperative Oncology Group; ELN: European LeukemiaNet; ESMO; European Society for Medical Oncology; EZ: etoposide; FLAG: fludarabine, cytarabine and granulocyte colony stimulating factor; FLAG-IDA: fludarabine, cytarabine and granulocyte colony stimulating factor plus idarubicin; FLT3+: FMS-like tyrosine kinase 3 mutation positive; FLT3-ITD+: FMS-like tyrosine kinase 3 - internal tandem duplication mutation positive; G-CSF: granulocyte colony stimulating factor; GO: gemtuzumab ozogamicin; GPOH: Society for Paediatric Haematology/Oncology; HiDAC: high-dose cytarabine; HLA: human leukocyte antigen; HMA: hypomethylating agents; HSCT: haematopoietic stem cell transplantation; IDAC: intermediate dose of cytarabine; IDH1+: isocitrate dehydrogenase 1 mutation positive; IDH2+: isocitrate dehydrogenase 2 mutation positive; IV: intravenous; JSH: Japanese Society of Haematology; LCA: London Cancer Alliance; MEC: mitoxantrone, etoposide, and cytarabine; NCCN: National Comprehensive Cancer Network; NCI: National Cancer Institute; NHS: National Health Service; NOSCAN: North of Scotland Cancer Network; ; OeGHO: Austrian Society for Haematology \& Medical Oncology; PS: performance score; PDQ: Physician Data Query; R/R: relapsed or refractory; SC: subcutaneous; SGH-SSH: Swiss Society for Haematology; SSMO/SSOM/SGMO: Swiss Society of Medical Oncology; UK: United Kingdom.

\subsubsection{What is the current management of FLT3+R/R \\ AML?}

Recommendations for the management of patients with FLT3+ R/R AML are summarised in 
Table 0-1.

Only the NCCN and LCA guidelines provide specific recommendations for patients with FLT3+ R/R AML. However, very few recommendations are issued for this patient population in these two guidelines.

NCCN 2018 recommend gilteritinib [category 2A] if FLT3+ and sorafenib plus HMA (5-azacitidine or decitabine) if FLT3-
ITD+ AML. In contrast, LCA guidelines recommend alloHSCT over chemotherapy in young individuals, particularly for those under 40 years of age with adverse risk molecular profiles, such as FLT3-ITD+ and NPM1-wild type AML.

The German guidelines did mention that two tyrosine kinase inhibitors (TKIs; gilteritinib and quizartinib) are being assessed in FLT3+ R/R AML clinical trials but do not provide any specific recommendations [Onkopedia 2018]. 
International Journal of Engineering Applied Sciences and Technology, 2020

Vol. 4, Issue 9, ISSN No. 2455-2143, Pages 61-83

Published Online January 2020 in IJEAST (http://www.ijeast.com)

Table 0-1 Key recommendations for patients with FLT3+ R/R AML

\begin{tabular}{|l|l|l|}
\hline $\begin{array}{l}\text { Reference } \\
\text { US }\end{array}$ & Association & \multicolumn{1}{|c|}{ Recommendation for R/R AML with mutations } \\
\hline $\begin{array}{l}\text { NCCN } \\
\mathbf{2 0 1 8}\end{array}$ & NCCN & $\begin{array}{l}\text { Therapy for FLT3-ITD+ R/R AML } \\
\bullet \text { Gilteritinib } \\
\bullet \text { HMAs (5-azacitidine or decitabine) + sorafenib }\end{array}$ \\
\hline UK & \multicolumn{2}{|c|}{$\begin{array}{l}\bullet \text { In young individuals, particularly those under 40 with adverse risk molecular } \\
\text { profiles, such as FLT3-ITD+ and NPM1-wild type, serious consideration } \\
\text { should be given to the benefit of allo-HSCT in first CR versus chemotherapy }\end{array}$} \\
\hline $\begin{array}{l}\text { LCA } \\
\text { 2015 }\end{array}$ & LCA
\end{tabular}

Abbreviations: allo-HSCT: allogeneic haematopoietic stem cell transplantation; AML: acute myeloid leukaemia; CR: complete remission; FLT3+: FMS-like tyrosine kinase 3 mutation positive; FLT3-ITD+: FMS-like tyrosine kinase 3 - internal tandem duplication mutation positive; HMA: hypomethylating agents; LCA: London Cancer Alliance; NCCN: National Comprehensive Cancer Network; NPM1: nucleophosmin1; R/R: relapsed or refractory.

\subsubsection{Treatment patterns in clinical practice}

\section{Table 0-2.}

Both studies [Griffin 2019**; Wolf 2018] provide real-world data on treatment patterns for patients with $\mathrm{R} / \mathrm{R}$ AML including patients with FLT3+ AML.

Griffin 2019 report the results of a retrospective chart study by haematologists and oncologists from 10 countries (US, Canada, UK, France, Germany, Italy, Spain, Netherlands, Japan, and South Korea). Griffin 2019 report data for 1027 patients of which 181 and 182 had FLT3+ and FLT3 wild type R/R AML, respectively. Patients with FLT3+ and FLT3 wild type R/R AML received the same therapies. The most commonly prescribed treatment for patients with $\mathrm{R} / \mathrm{R}$ AML was BSC (FLT3+: 39.8\%; FLT3 wild type: 24.7\%) regardless of FLT3 status followed by standard to intermediate dose of cytarabinebased therapies (FLT3+: 12.7\%; FLT3 wild type: 19.2\%), HMA-based therapies (FLT3+: 9.4\%; FLT3 wild type: 16.5\%) and low dose cytarabine-based therapies (FLT3+: 9.4\%; FLT3 wild type: $15.4 \%)$. A higher proportion of patients with FLT3+ R/R AML received a HSCT (FLT3+: 23.6\%; FLT3 wild type:
Two studies providing real world data regarding treatment patterns for the management of R/R AML were identified in the literature review. An overview of these studies is provided in

$18.1 \%$ ). Overall, $40 \%$ of patients with R/R AML received treatments that were not aligned with treatment guidelines [Griffin 2019]. Aditional information on the treatments patients with FLT3+ R/R AML received is provided in Appendix VII.

Wolf 2018 report the outcomes of an audit at the UHBristol NHS Trust against clinical Quality Performance Indicators set by the Scottish Cancer Taskforce. Of all the patients with AML treated at their centre, 16 developed R/R AML. These patients corresponded to $34 \%$ of all patients receiving intense induction therapy. The treatment these patients received when they developed R/R AML included intensive salvage chemotherapy for ten patients (CPX-351 in three patients, FLAG-IDA in six patients, quizartinib in one patient), non-intensive therapy for four patients (with azacitidine [ 1 to 15 cycles; longest follow up not yet reached]) and palliation alone for two patients. Of the ten patients who received salvage chemotherapy, four received a HSCT following the salvage therapy [Wolf 2018].
** The initial SLR identified Griffin 2017 which was a presentation at ASH 2017, during the finalisation of this report, Griffin 2019 was identified. This publication was first online on December 22. Griffin 2019 provides more data than Griffin 2017 and replaces the latter. In this SLR, Griffin 2019 but not Griffin 2017 is included. 
International Journal of Engineering Applied Sciences and Technology, 2020

Vol. 4, Issue 9, ISSN No. 2455-2143, Pages 61-83

Published Online January 2020 in IJEAST (http://www.ijeast.com)

Table 0-2 Studies providing data regarding management patterns in real world clinical practice

\begin{tabular}{|c|c|c|c|c|c|}
\hline Reference & $\begin{array}{l}\text { Geographic } \\
\text { scope and } \\
\text { timeframe }\end{array}$ & Study design & Objective & $\begin{array}{c}\text { Study } \\
\text { population }\end{array}$ & Study outcomes \\
\hline $\begin{array}{l}\text { Griffin } \\
2019\end{array}$ & $\begin{array}{l}10 \text { countries } \\
\text { (US, Canada, } \\
\text { UK, France, } \\
\text { Germany, Italy, } \\
\text { Spain, } \\
\text { Netherlands, } \\
\text { Japan, and South } \\
\text { Korea) }\end{array}$ & $\begin{array}{l}\text { Retrospective } \\
\text { chart analysis } \\
\text { by } \\
\text { haematologists } \\
\text { and } \\
\text { oncologists }\end{array}$ & $\begin{array}{l}\text { To evaluate } \\
\text { Tx patterns } \\
\text { and HRU } \\
\text { among adults } \\
\text { with AML } \\
\text { using RWE }\end{array}$ & $\begin{array}{l}\text { Patients with } \\
\text { AML } \\
\text { (n=1027): } \\
\text { - Newly } \\
\text { diagnosed } \\
\text { FLT3+<65 } \\
\text { and } \geq 65 \\
\text { - Newly } \\
\text { diagnosed } \\
\text { FLT3-<65 } \\
\text { and } \geq 65 \\
\text { - R/R FLT3+ } \\
\text { - R/R FLT3- }\end{array}$ & $\begin{array}{l}\text { Most common initial Tx among } \\
\text { patients with FLT3+ R/R AML: } \\
\text { - BSC only: } 39.8 \% \\
\text { - SDAC-based therapies: } 12.7 \% \\
\text { - HMA-based therapies: } 9.4 \% \\
\text { - LoDAC-based therapies: } 9.4 \% \\
\text { - HDAC: } 2.8 \% \\
\text { Among patients with R/R FLT3- AML: } \\
\text { - BSC only: } 24.7 \% \\
\text { - SDAC-based therapies: } 19.2 \% \\
\text { - HMA-based therapies: } 16.5 \% \\
\text { - LoDAC-based therapies: } 15.4 \% \\
\text { - HDAC: } 11.5 \% \\
\text { Patients receiving non-guideline } \\
\text { recommended Tx: } \\
\text { - ND patients: } 20-60 \% \\
\text { - R/R patients: } 40 \% \\
\text { Patients who received HSCT: } \\
\text { - R/R FLT3+: } 23.6 \% \\
\text { - R/R FLT3-: } 18.1 \%\end{array}$ \\
\hline Wolf 2018 & $\begin{array}{l}\text { UK } \\
2016 / 2017\end{array}$ & $\begin{array}{l}\text { Audit at the } \\
\text { UHBristol } \\
\text { NHS Trust } \\
\text { against } \\
\text { clinical QPIs } \\
\text { set by the } \\
\text { Scottish } \\
\text { Cancer } \\
\text { Taskforce }\end{array}$ & $\begin{array}{l}\text { To evaluate } \\
\text { the use of } \\
\text { QPIs to } \\
\text { monitor and } \\
\text { report } \\
\text { progress } \\
\text { towards set } \\
\text { quality } \\
\text { standards in } \\
\text { treatment of } \\
\text { AML }\end{array}$ & Adult AML & $\begin{array}{l}\text { R/R AML: } 16 \text { (34\%) of intensively } \\
\text { treated patients } \\
\text { - } 10 \text { patients received intensive salvage } \\
\text { chemotherapy ( } 3 \text { x CPX-351, } 6 \text { x } \\
\text { FLAG-IDA, } 1 \text { x quizartinib) } \\
\text { - } 4 / 10 \text { patients received HSCT } \\
\text { following the salvage therapy } \\
\text { - } 4 \text { received non-intensive therapy with } \\
\text { azacitidine ( } 1 \text { to } 15 \text { cycles; longest } \\
\text { follow up not yet reached) } \\
\text { - } 2 \text { patients were for palliation alone }\end{array}$ \\
\hline
\end{tabular}

Abbreviations: AML: acute myeloid leukaemia; BSC: best supportive care; FLAG-IDA: fludarabine, cytarabine and G-CSF plus idarubicin; FLT3+: FMS-like tyrosine kinase 3 mutated; FLT3-: FMS-like tyrosine kinase 3 wild type; HMA: hypomethylating agents; HRU: health-resource utilisation; HDAC: high dose cytarabine; HSCT: haematopoietic stem cell transplantation; LoDAC: low-dose cytarabine; ND: newly diagnosed; NHS: National Health Service; QPI: quality performance indicators; R/R: relapsed or refractory; RWE: real world evidence; SDAC: standard to intermediate dose of cytarabine; Tx: treatment; UK: United Kingdom; US: United States.

\subsection{CONCLUSIONS OF THE CLINICAL MANAGEMENT REVIEW}

Overall, 12 guidelines and two evidence-based reviews of the current management of R/R AML were included in the literature review. The reviewed guidelines included two guidelines with US coverage [NCCN 2018; PDQ 2018], two with pan-European coverage [Fey 2013; Döhner 2017], one for Germany [Onkopedia 2018], five for the UK [NOSCAN 2017;
LCA 2015; Mulligan 2006; NHS Anglia 2013; NHS Birmingham 2011] and one for Japan [Miyawaki 2017]. No recent guidelines were identified for France, Italy or Spain. The NCCN guidelines abstracted in this SLR correspond to those published in November 2018, i.e., version 3.

All 12 guidelines included in this SLR covered all stages of AML. None of them focused on R/R AML or FLT3+ AML.

All guidelines provide similar recommendations regarding therapeutic options for R/R AML, and include salvage therapy, offering participation in a clinical trial with new interventions, and BMT. The only exception is Mulligan 2006 which highlight 


\section{International Journal of Engineering Applied Sciences and Technology, 2020 \\ Vol. 4, Issue 9, ISSN No. 2455-2143, Pages 61-83 \\ Published Online January 2020 in IJEAST (http://www.ijeast.com)}

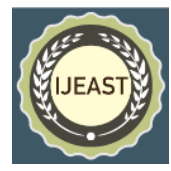

that there is no clear evidence of the benefit of BMT in patients with R/R AML. However, these guidelines are older than all the other guidelines and since the publication of Mulligan 2006, evidence of the benefit of BMT in R/R AML has become available. NCCN 2018 recommend conducting molecular profiling including FLT3 mutations to guide selection of therapy.

NCCN [NCCN 2018], ELN [Döhner 2017] and JSH [Miyawaki 2017] guidelines recommend participation in a clinical trial as the best therapeutic option for patients with $\mathrm{R} / \mathrm{R}$ AML. The NCCN guidelines highlight that several trials with targeted therapies for R/R AML with specific mutations were ongoing at the time of issuing the guidelines. In addition, they recommend gilteritinib for FLT3+ R/R AML [NCCN 2018].

The ELN guidelines recommend the " $7+3$ " induction therapy for all patients who are eligible for intensive chemotherapy and azacitidine, decitabine or LoDAC until progression, or BSC including hydroxyurea for patients who cannot tolerate any antileukaemic therapy, or who do not wish any therapy [Döhner 2017]. Common salvage regimens for patients who are refractory to a first induction cycle or with relapsed disease, include IDAC with or without daunorubicin, idarubicin or mitoxantrone if candidates for intensive therapy [Döhner 2017; Onkopedia 2018; LCA 2015; Miyawaki 2017]. If not eligible for intensive salvage therapy, HMA should be considered [Onkopedia 2018]. NOSCAN 2017 and LCA 2015 also recommend FLAG with or without idarubicin.

Consolidation therapy after induction for patients with $\mathrm{R} / \mathrm{R}$ AML aged 18 to $60 / 65$ years of age in the ELN guidelines is based on the patient's risk status. For patients with favourablerisk genetics, 2-4 cycles of IDAC is recommended. For patients with intermediate-risk genetics, consolidation therapy consists of allo-HSCT from matched-related or unrelated donor, 2-4 cycles of IDAC, or high-dose therapy and auto-HSCT. For patients with adverse-risk genetics, allo-HSCT from matchedrelated or unrelated donor is the recommended consolidation therapy. Consolidation therapy for patients older than 60/65 years of age also depends on the risk classification. For patients with favourable-risk genetics, consolidation consists of 2-3 cycles of IDAC. For patients with intermediate/adverse-risk genetics, an allo-HSCT or investigational therapy should be considered [Döhner 2017].

The LCA guidelines recommend BSC with or without cytoreductive chemotherapy (hydroxyurea, etoposide, mitoxantrone, or cytarabine [subcutaneously or continuous infusion]), a combination of amsacrine, cytarabine, and etoposide, or EZ (etoposide) if the patient is not eligible to HSCT or fails to respond to re-induction therapy [LCA 2015].

Only the NCCN and LCA guidelines provide specific recommendations for patients with FLT3+ R/R AML [LCA 2015; NCCN 2018]. NCCN 2018 recommend gilteritinib for patients with FLT3+ R/R AML and sorafenib plus HMA for patients with FLT3-ITD+ AML. In contrast, LCA guidelines recommend allo-HSCT over chemotherapy in young individuals, particularly those under 40 with adverse risk molecular profiles, such as FLT3-ITD+ and NPM1 wild type AML.

In a retrospective chart review which included data collected by physicians from 10 countries, the most commonly prescribed treatment for R/R AML was BSC (FLT3+: 39.8\%; FLT3 wild type: $24.7 \%$ ) regardless of FLT3 status followed by standard to intermediate dose of cytarabine -based therapies (FLT3+: 12.7\%; FLT3 wild status: 19.2\%), HMA-based therapies (FLT3+: 9.4\%; FLT3 wild type: 16.5\%) and low dose cytarabine-based therapies (FLT3+: 9.4\%; FLT3 wild type: $15.4 \%$ ). Overall, $23.6 \%$ and $18.1 \%$ of patients with FLT3+ and FLT3 wild type R/R AML received an HSCT [Griffin 2019].

The literature review highlights the lack of specific recommendations for the treatment of patients with FLT3+ R/R AML. NCCN guidelines are the only ones that provide specific therapies for these patients.

\section{REFERENCES}

Aly, A., Bapat, B., Ray, S., Chen, Z. and Botteman, M., 2017. Economic Burden of Relapsed/Refractory (R/R) Acute Myeloid Leukemia (AML) in the US.

Arber, D. A., Borowitz, M. J., Cessna, M., Etzell, J., Foucar, K., Hasserjian, R. P., ... \& Rumble, R. B. (2017). Initial diagnostic workup of acute leukemia: guideline from the College of American Pathologists and the American Society of Hematology. Archives of pathology \& laboratory medicine, 141(10), 1342-1393.

Casey K.L., Aljitawi O.S., Ganguly S., Abhyankar S., Fleming A., Male H., McGuirk J.P., Lin T.L., 2013. Efficacy and relative costs of re-induction chemotherapy with clofarabine and cytarabine for adults with AML. Blood. Conference: 55th Annual Meeting of the American Society of Hematology, ASH 2013. New Orleans, LA United States. Conference Publication: (var.pagings). 122 (21) (no pagination), 2013.

Castejón, N., Cappelleri, J.C., Cuervo, J., Lang, K., Mehta, P., Mokgokong, R. and Mamolo, C., 2017. Estimating health state utilities for patients with acute myeloid leukemia. Value in Health (Vol. 20, No. 5, pp. A224-A224).

Castejón, N., Cappelleri, J.C., Cuervo, J., Lang, K., Mehta, P., Mokgokong, R. and Mamolo, C., 2018. Social preferences for health states associated with acute myeloid leukemia for patients undergoing treatment in the United Kingdom. Health and quality of life outcomes, 16(1), p.66.

NICE TA399: Azacitidine for treating acute myeloid leukaemia with more than $30 \%$ bone marrow blasts. Available via https://www.nice.org.uk/guidance/ta399. Accessed on December 09, 2018. 


\section{International Journal of Engineering Applied Sciences and Technology, 2020 \\ Vol. 4, Issue 9, ISSN No. 2455-2143, Pages 61-83 \\ Published Online January 2020 in IJEAST (http://www.ijeast.com)}

Chevallier, P., Prebet, T., Pigneux, A., Hunault, M., Delaunay, J., Perry, F., Lode, L., Richebourg, S., Blanchet, O., Vey, N. and Ifrah, N., 2010. Influence of NPM1 and FLT3-ITD status on outcome in relapsed/refractory AML patients receiving salvage therapy including gemtuzumab ozogamicin. Leukemia, 24(2), p.467.

Cortes, J.E., Tallman, M.S., Schiller, G., Trone, D., Gammon, G., Goldbert, S., Perl., A.E., Marie., J.P., Martinelli, G., Levis., M., 2013. Results of a phase 2 randomized, open-label, study of lower doses of quizartinib (AC220; ASP2689) in subjects with FLT3-ITD positive relapsed or refractory acute myeloid leukemia (AML). Blood. Conference: 55th Annual Meeting of the American Society of Hematology, ASH 2013. New Orleans, LA United States. Conference Publication: (var.pagings). 122 (21) (no pagination), 2013.

Cortes, J. E., Kantarjian, H., Foran, J. M., Ghirdaladze, D., Zodelava, M., Borthakur, G., ... \& Levis, M. (2013). Phase I study of quizartinib administered daily to patients with relapsed or refractory acute myeloid leukemia irrespective of FMS-like tyrosine kinase 3-internal tandem duplication status. Journal of clinical oncology, 31(29), 3681.

Cortes, J.E., Kantarjian, H.M., Kadia, T.M., Borthakur, G., Konopleva, M., Garcia-Manero, G., Daver, N.G., Pemmaraju, N., Jabbour, E., Estrov, Z. and Ramachandran, A., 2016. Crenolanib besylate, a type I pan-FLT3 inhibitor, to demonstrate clinical activity in multiply relapsed FLT3-ITD and D835 AML.

Cortes, J., Gammon, G., Khaled, S., Martinelli, G., Kramer, A., Steffen, B., Hogge, D., Jonas, B.A., Dombret, H. and Perl, A., 2016. Phase 3 study of quizartinib (AC220) monotherapy vs salvage chemotherapy (SC) in patients (pts) with FLT3-ITD+ acute myeloid leukemia (AML) refractory to or relapsed (R/R) after 1st-line treatment with or without hematopoietic stem cell transplant (HSCT) consolidation: the QuANTUM-R study. Annals of Oncology, 27(suppl_6).

Cortes, J.E., Tallman, M.S., Schiller, G.J., Trone, D., Gammon, G., Goldberg, S.L., Perl, A.E., Marie, J.P., Martinelli, G., Kantarjian, H.M. and Levis, M.J., 2018. Phase 2b study of two dosing regimens of quizartinib monotherapy in FLT3-ITD mutated, relapsed or refractory AML. Blood, pp.blood-2018.

Cortes, J., Perl, A.E., Döhner, H., Kantarjian, H., Martinelli, G., Kovacsovics, T., Rousselot, P., Steffen, B., Dombret, H., Estey, E. and Strickland, S., 2018. Quizartinib, an FLT3 inhibitor, as monotherapy in patients with relapsed or refractory acute myeloid leukaemia: an open-label, multicentre, single-arm, phase 2 trial. The Lancet Oncology.

Cortes, J., 2018. QuANTUM-R EHA 2018. Oral presentation at European Hematology Association (EHA) conference 2018:
Quizartinib significantly prolongs overall survival in patients with FLT3-ITD-mutated relapsed-refractory AML in the phase 3, randomized, controlled QuANTUM-R trial

Cortes, J., 2018. QuANTUM-R ASH 2018. Oral presentation at American Society of Hematology (ASH) conference 2018: QuANTUM-R in Relapsed/Refractory FLT3-ITD AML

Cortes, J.E., Khaled, S.K., Martinelli, G., Perl, A.E., Ganguly, S., Russell, N.H., Kramer, A., Dombret, H., Hogge, D., Jonas, B.A. and Leung, A.Y.H., 2018. Efficacy and Safety of SingleAgent Quizartinib (Q), a Potent and Selective FLT3 Inhibitor (FLT3i), in Patients (pts) with FLT3-Internal Tandem Duplication (FLT3-ITD)-Mutated Relapsed/Refractory (R/R) Acute Myeloid Leukemia (AML) Enrolled in the Global, Phase 3, Randomized Controlled Quantum-R Trial. www.ClinicalTrials.Gov

Daver, N., Assi, R., Garcia-Manero, G., Ravandi, F., Borthakur, G., Jabbour, E.J., DiNardo, C.D., Kadia, T., Ning, J., González, G.N. and Pierce, S., 2017. a Phase I/II Study of Selinexor (SEL) with Sorafenib in Patients (pts) with Relapsed and/or Refractory (R/R) FLT3 Mutated Acute Myeloid Leukemia (AML).

Döhner, H., Estey, E., Grimwade, D., Amadori, S., Appelbaum, F. R., Büchner, T., ... \& Levine, R. L. (2017). Diagnosis and management of AML in adults: 2017 ELN recommendations from an international expert panel. Blood, 129(4), 424-447.

Fleischmann M.; Schrenk K.G.; Schnetzke U.; Hilgendorf I.; Hochhaus A.; Scholl S., 2016. Evaluation of tyrosine kinase inhibitor treatment in patients with FLT3-ITD positive acute myeloid leukemia. ncology Research and Treatment. Conference: Jahrestagung der Deutschen, Osterreichischen und Schweizerischen Gesellschaften fur Hamatologie und Medizinische Onkologie 2016. Germany. 39 (Supplement 3) (pp 50-51), 2016.

Fleischmann, M., Schnetzke, U., Schrenk, K.G., Schmidt, V., Sayer, H.G., Hilgendorf, I., Hochhaus, A. and Scholl, S., 2017. Outcome of FLT3-ITD-positive acute myeloid leukemia: impact of allogeneic stem cell transplantation and tyrosine kinase inhibitor treatment. Journal of cancer research and clinical oncology, 143(2), pp.337-345.

Forsythe, A., Brandt, P.S., Dolph, M., Patel, S., Rabe, A.P.J. and Tremblay, G., 2018. Systematic review of health state utility values for acute myeloid leukemia. ClinicoEconomics and Outcomes Research: CEOR, 10, p.83.

De Freitas, T., Marktel, S., Piemontese, S., Carrabba, M.G., Tresoldi, C., Messina, C., Lupo Stanghellini, M.T., Assanelli, A., Corti, C., Bernardi, M. and Peccatori, J., 2016. High rate of hematological responses to sorafenib in FLT 3-ITD acute 


\section{International Journal of Engineering Applied Sciences and Technology, 2020 \\ Vol. 4, Issue 9, ISSN No. 2455-2143, Pages 61-83 \\ Published Online January 2020 in IJEAST (http://www.ijeast.com)}

myeloid leukemia relapsed after allogeneic hematopoietic stem cell transplantation. European journal of haematology, 96(6), pp.629-636.

Fey, M. F., \& Buske, C. (2013). Acute myeloblastic leukaemias in adult patients: ESMO Clinical Practice Guidelines for diagnosis, treatment and follow-up. Annals of oncology, 24, vi138-vi143.

Gorcea, C.M., Burthem, J. and Tholouli, E., 2018. ASP2215 in the treatment of relapsed/refractory acute myeloid leukemia with FLT3 mutation: background and design of the ADMIRAL trial. Future Oncology, 14(20), pp.1995-2004.

Griffin, J.D., Shah, M.V., Song, Y. and Yang, H., 2018. Treatment Patterns and Healthcare Resource Utilization (HRU) in Patients with Relapsed/Refractory (R/R) FLT3-Mutated (FLT3mut) and FLT3-Wild Type (FLT3wt) Acute Myeloid Leukemia (AML): A Multi-Country Medical Chart Study.

Griffin JD, Yang H, Song Y, Kinrich D, Shah M, Bui CN. Treatment Patterns and Healthcare Resource Utilization in Patients with FLT3-Mutated and Wild Type Acute Myeloid Leukemia: A Medical Chart Study. Eur J Haematol. 2018 Dec 22. doi: 10.1111/ejh.13205. [Epub ahead of print]

HAS. Guide- affection de longue durée. ALD n³0. Tumeur maligne, affection maligne du tissu lymphatique ou hématopoiétique Leucémies aiguës de l'adulte. November 2011. Available at: https://www.hassante.fr/portail/upload/docs/application/pdf/201202/ald_30_gm_leucemies_aigues_adulte_web.pdf. Accessed on December 01, 2018.

HAS. Actes et prestations - affection de longue durée. ALD $\mathrm{n}^{\circ} 30$. Tumeur maligne, affection maligne du tissu lymphatique ou hématopoïétique Leucémies aiguës de l'adulte. January 2015. Available at: https://www.hassante.fr/portail/upload/docs/application/pdf/2012-

02/ald_30_lap_la_final.web.pdf. Accessed on December 01, 2018.

Hensen M., Joshi N., Xu W., Patel S., Bal V., Lasch K., 2017. Assessment of utility values for treatment-related health states of acute myeloid leukemia in the United Kingdom. Value in Health. Conference: ISPOR 22nd Annual International Meeting. United States. 20 (5) (pp A115), 2017.

Hills, R.K., Gammon, G., Trone, D. and Burnett, A.K., 2015. Quizartinib significantly improves overall survival in FLT3ITD positive AML patients relapsed after stem cell transplantation or after failure of salvage chemotherapy: a comparison with historical AML database (UK NCRI data).

Hodgson R, Biswas M, Morgan P, Mebrahtu T, Harden M, Woolacott N. Midostaurin for untreated acute myeloid leukaemia: A Single Technology Appraisal. CRD and CHE, University of York, Technology Assessment Group, 2017.

Irish, W., Ryan, M., Gache, L., Gunnarsson, C., Bell, T. and Shapiro, M., 2017. Acute myeloid leukemia: a retrospective claims analysis of resource utilization and expenditures for newly diagnosed patients from first-line induction to remission and relapse. Current medical research and opinion, 33(3), pp.519-527.

Iyer, S.P., Jethava, Y., Karanes, C., Eckardt, J.R. and Collins, R., 2016. Safety study of salvage chemotherapy high-dose Ara$\mathrm{C}$ /mitoxantrone (HAM) and type I FLT3-TKI crenolanib in first relapsed/primary refractory AML.

Joshi, N., Hensen, M., Patel, S., Xu, W., Lasch, K. and Stolk, E., 2018. Health State Utilities for Acute Myeloid Leukaemia: A Time Trade-off Study. PharmacoEconomics, pp.1-8.

Kurosawa, S., Yamaguchi, T., Miyawaki, S., Uchida, N., Kanamori, H., Usuki, K., Yamashita, T., Watanabe, M., Yakushiji, K., Yano, S. and Nawa, Y., 2011. A Markov decision analysis of allogeneic hematopoietic cell transplantation versus chemotherapy in patients with acute myeloid leukemia in first remission. Blood, 117(7), pp.2113-2120.

Kwon, C., Brandt, P., Manson, S., Fuentes-Alburo, A. and Forsythe, A., 2017. Treatment Patterns and Health Care Resources Use (HCRU) in Patients with Acute Myeloid Leukemia (AML): Real World Evidence (RWE) from 30 US Institutions.

Labopin, M., Ruggeri, A., Gorin, N.C., Gluckman, E., Blaise, D., Mannone, L., Milpied, N., Yakoub-Agha, I., Deconinck, E., Michallet, M. and Fegueux, N., 2014. Cost-effectiveness and clinical outcomes of double versus single cord blood transplantation in adults with acute leukemia in France. haematologica, 99(3), pp.535-540.

Lachaine, J., Mathurin, K., Barakat, S. and Couban, S., 2015. Economic evaluation of arsenic trioxide compared to all-trans retinoic acid+ conventional chemotherapy for treatment of relapsed acute promyelocytic leukemia in Canada. European journal of haematology, 95(3), pp.218-229.

LCA Haemato-Oncology Clinica Guidelines: Part 2: Acute Myeloid Leukaemia. Available via http://www.londoncanceralliance.nhs.uk/information-forhealthcare-professionals/forms-and-guidelines/lca-forms,protocols-and-guidance/lca-haemato-oncology-clinicalguidelines/. Accessed on December 01, 2018. Leunis, A., Redekop, W.K., Uyl-de Groot, C.A. and Löwenberg, B., 2014. Impaired health-related quality of life in acute myeloid leukemia survivors: a single-center study. European journal of haematology, 93(3), pp.198-206. 


\section{International Journal of Engineering Applied Sciences and Technology, 2020 \\ Vol. 4, Issue 9, ISSN No. 2455-2143, Pages 61-83 \\ Published Online January 2020 in IJEAST (http://www.ijeast.com)}

Levis, M., Cortes, J., Perl, A., Döhner, H., Steffen, B., Rousselot, P., Martinelli, G., Estey, E., Burnett, A., Gammon, G., Trone, D., Dombret, H., 2013. High response rate and briding to hematopoietic stem cell transplantation with quizartinib (AC220) in patients with FLT3-ITD -positive relapsed/refractory acute myeloid leukemia (AML). Haematologica. Conference: 18th Congress of the European Hematology Association. Stockholm Sweden.

Lohmeyer, J., Nerreter, T., Dotterweich, J., Einsele, H. and Seggewiss-Bernhardt, R., 2018. Sorafenib paradoxically activates the RAS/RAF/ERK pathway in polyclonal human NK cells during expansion and thereby enhances effector functions in a dose-and time-dependent manner. Clinical \& Experimental Immunology.

Magar R.S.; Purdy C.; Hayward A.; Einarson T.R.; Burnett A.K., 2009. Cost-effectiveness analysis of histamine dihydrochloride + low dose interleukin-2 vs standard of care for acute myeloid leukemia patients in their first complete remission: A UK perspective. Value in Health. Conference: ISPOR 12th Annual European Congress. Paris France. Conference Publication: (var.pagings). 12 (7) (pp A272), 2009. Mahmoud, D., Skikne, B.S., Kucmin-Bemelmans, I., Alleman, C. and Hensen, M., 2012. Overall economic burden of total treatment costs in acute myeloid leukemia throughout the course of the disease.

Mamolo, C.M., Cappelleri, J.C., Hoang, C.J., Kim, R., Hadfield, A., Middleton, C., Rider, A. and Walter, R.B., 2017. Cross-Sectional Survey of Symptoms and Health-Related Quality of Life of Adults with De Novo Acute Myeloid Leukemia (AML) in Clinical Practice.

Manan, M.M., 2016, November. Medication cost of actue myeloid leukemia: a descriptive study. Value in Health (Vol. 19, No. 7, pp. A883-A883).

Manchester Cancer. Manchester Cancer Haemato-oncology Pathway: Guidelines for the management of Acute Myeloid Leukaemia. 2015

Martinelli, G., Perl, A.E., Dombret, H., Kayser, S., Steffen, B., Rousselot, P.H., Estey, E., Burnett, A.K., Shah, N.P., Gammon, G. and Trone, D., 2013. Effect of quizartinib (AC220) on response rates and long-term survival in elderly patients with FLT3-ITD positive or negative relapsed/refractory acute myeloid leukemia.

Martinelli, G., Levis, M.J., Perl, A.E., Dombret, H., Steffen, B., Rousselot, P., Estey, E.H., Shah, N.P., Gammon, G., Trone, D. and Cortes, J.E., 2014, June. Treatment with quizartinib (AC220) enables a high rate of patients with relapsed or refractory FLT3-ITD (+) acute myeloid leukemia to be bridged to HSCT. In Haematologica (Vol. 99, pp. 35-35).
Medeiros, B.C., Pandya, B.J., Chen, C.C., Groves, E.S., Bui, C.N., Horvath, L.E. and Wade, R.L., 2017. Economic Burden of Treatment Episodes in Acute Myeloid Leukemia (AML) Patients in the US: A Retrospective Analysis of a Commercial Payer Database.

Metzelder, S., Wang, Y., Wollmer, E., Wanzel, M., Teichler, S., Chaturvedi, A., Eilers, M., Enghofer, E., Neubauer, A. and Burchert, A., 2009. Compassionate use of sorafenib in FLT3ITD-positive acute myeloid leukemia: sustained regression before and after allogeneic stem cell transplantation. Blood, 113(26), pp.6567-6571.

Metzelder, S.K., Wollmer, E., Neubauer, A. and Burchert, A., 2010. Sorafenib in relapsed and refractory FLT3-ITD positive acute myeloid leukemia: a novel treatment option. Deutsche medizinische Wochenschrift (1946), 135(38), pp.1852-1856.

Metzelder, S.K., Schroeder, T., Finck, A., Scholl, S., Fey, M., Götze, K., Linn, Y.C., Kröger, M., Reiter, A., Salih, H.R. and Heinicke, T., 2012. High activity of sorafenib in FLT3-ITDpositive acute myeloid leukemia synergizes with allo-immune effects to induce sustained responses. Leukemia, 26(11), p.2353.

Metzelder, S.K., Schroeder, T., Lübbert, M., Ditschkowski, M., Götze, K., Scholl, S., Meyer, R.G., Dreger, P., Basara, N., Fey, M.F. and Salih, H.R., 2017. Long-term survival of sorafenibtreated FLT3-ITD-positive acute myeloid leukaemia patients relapsing after allogeneic stem cell transplantation. European journal of cancer, 86, pp.233-239.

British Committee for Standards in Haematology, Milligan DW, Grimwade D, Cullis JO, Bond L, Swirsky D, Craddock C, Kell J, Homewood J, Campbell K, McGinley S, Wheatley K, Jackson G. Guidelines on the management of acute myeloid leukaemia in adults. Br J Haematol. 2006 Nov;135(4):450-74. Epub 2006 Oct 10.

Miyawaki, S. (2017). JSH guideline for tumors of hematopoietic and lymphoid tissues: leukemia 1. Acute myeloid leukemia (AML). International journal of hematology, 106(3), 310-325.

NCCN Guidelines for Patients. Available via https://www.nccn.org/patients/guidelines/aml/index.html. Accessed on December 01, 2018.

National Health Service. Guidelines for the diagnosis and management of Adult Acute Leukaemia within Anglia Cancer Network. Anglia Cancer Network. 2013.

National Health Service. Guidelines for the Management of Acute Myeloid Leukaemia in Adults. Pan Birmingham Cancer Network. 2011. 


\section{International Journal of Engineering Applied Sciences and Technology, 2020 \\ Vol. 4, Issue 9, ISSN No. 2455-2143, Pages 61-83 \\ Published Online January 2020 in IJEAST (http://www.ijeast.com)}

NICE pathways in blood and bone marrow cancers - everything NICE says in an interactive flow chart. Available via https://pathways.nice.org.uk/pathways/blood-and-bonemarrow-cancers\#path=view\%3A/pathways/blood-and-bonemarrow-cancers/myeloid-leukaemia.xml\&content=viewindex. Accessed on December 01, 2018.

North of Scotland Cancer Network: Clinical Management Guidelin for Acute Myeloid Leukaemia. Available via http://www.noscan.scot.nhs.uk/guidelinesandprotocols/Tumou r \%20specific\%20CMGs/Haematology/Documents/NOSCAN $\% 20$ AML\%20CMG\%20V1\%20+.pdf. Accessed on December 01, 2018.

ID894. Single technology appraisal. Midostaurin for newly diagnosed acute myeloid leukaemia. Manufacturer submission. Onkopedia: Akute Myeloische Leukämie (AML). Available via https://www.onkopedia.com/de/onkopedia/guidelines/akutemyeloische-leukaemie-aml/@@view/html/index.html.

Accessed on December 01, 2018.

Pan, F., Peng, S., Fleurence, R., Linnehan, J.E., Knopf, K. and Kim, E., 2010. Economic analysis of decitabine versus best supportive care in the treatment of intermediate-and high-risk myelodysplastic syndromes from a US payer perspective. Clinical therapeutics, 32(14), pp.2444-2456.

Pandya, B.J., Medeiros, B.C., Chen, C.C., Wilson, S., Groves, E.S., Horvath, L.E. and Wade, R.L., 2017. Real-World Occurrence of Symptoms and Toxicities and Associated Cost Implications in Acute Myeloid Leukemia (AML) Treatment Episodes: A Retrospective Database Analysis in the US. National Cancer Institute's Physician's Data Query. Available via https://www.cancer.gov/publications/pdq. Accessed on December 01, 2018.

Perl, A. E., Altman, J. K., Cortes, J. E., Smith, C. C., Litzow, M., Baer, M. R., ... \& Jurcic, J. G. (2016). Final results of the Chrysalis trial: a first-in-human phase 1/2 dose-escalation, dose-expansion study of gilteritinib (ASP2215) in patients with relapsed/refractory acute myeloid leukemia (R/R AML).

Perl, A.E., Cortes, J.E., Strickland, S.A., Ritchie, E.K., Neubauer, A., Martinelli, G., Naoe, T., Pigneux, A., Rousselot, P.H., Röllig, C. and Baer, M.R., 2017. An open-label, randomized phase III study of gilteritinib versus salvage chemotherapy in relapsed or refractory FLT3 mutation-positive acute myeloid leukemia.

Perl, A. E., Altman, J. K., Cortes, J., Smith, C., Litzow, M., Baer, M. R., ... \& Jurcic, J. G. (2017). Selective inhibition of FLT3 by gilteritinib in relapsed or refractory acute myeloid leukaemia: a multicentre, first-in-human, open-label, phase 12 study. The Lancet Oncology, 18(8), 1061-1075.
Randhawa, J.K., Kantarjian, H.M., Borthakur, G., Thompson, P.A., Konopleva, M., Daver, N., Pemmaraju, N., Jabbour, E., Kadia, T.M., Estrov, Z. and Ramachandran, A., 2014. Results of a phase II study of crenolanib in relapsed/refractory acute myeloid leukemia patients (Pts) with activating FLT3 mutations.

Rautenberg, C., Nachtkamp, K., Dienst, A., Schmidt, P.V., Heyn, C., Kondakci, M., Germing, U., Haas, R., Kobbe, G. and Schroeder, T., 2017. Sorafenib and azacitidine as salvage therapy for relapse of FLT 3-ITD mutated AML after allo-SCT. European journal of haematology, 98(4), pp.348-354.

Ravandi, F., Alattar, M.L., Grunwald, M.R., Rudek, M.A., Rajkhowa, T., Richie, M.A., Pierce, S., Daver, N., GarciaManero, G., Faderl, S. and Nazha, A., 2013. Phase II study of azacitidine plus sorafenib in patients with acute myeloid leukemia and FLT-3 internal tandem duplication mutation. Blood, pp.blood-2013.

Retzler, J., Smith, A.B. and Chung, K.C., 2017. Health utilities in acute myeloid leukemia: a comprehensive literature review. Value in Health (Vol. 20, No. 5, pp. A115-A115).

Russell, N., Tallman, M.S., Goldberg, S., Perl, A.E., Marie, J.P., Martinelli, G., Larson, R.A., Schiller, G., Trone, D., Gammon, G. and Levis, M., 2014, June. Quizartinib (AC220) in patients with FLT3-ITD (+) relapsed or refractory acute myeloid leukemia: final results of a randomized phase 2 study. In Haematologica (Vol. 99, pp. 36-36).

Schnetzke, U., Fix, P., Spies-Weisshart, B., Schrenk, K., Glaser, A., Fricke, H.J., La Rosée, P., Hochhaus, A. and Scholl, S., 2014. Efficacy and feasibility of cyclophosphamide combined with intermediate-dose or high-dose cytarabine for relapsed and refractory acute myeloid leukemia (AML). Journal of cancer research and clinical oncology, 140(8), pp.1391-1397. Schroeder, T., Saure, C., Bruns, I., Zohren, F., Czibere, A.G., Safaian, N.N., Fenk, R., Haas, R. and Kobbe, G., 2009. Clinical Efficacy of Sorafenib in Patients with Acute Myeloid Leukemia (AML) and Activating FLT3-Mutations.

Sharma, M., Ravandi, F., Bayraktar, U.D., Chiattone, A., Bashir, Q., Giralt, S., Chen, J., Qazilbash, M., Kebriaei, P., Konopleva, M. and Andreeff, M., 2011. Treatment of FLT3ITD-positive acute myeloid leukemia relapsing after allogeneic stem cell transplantation with sorafenib. Biology of Blood and Marrow Transplantation, 17(12), pp.1874-1877.

Sid, S., Rey, J., Charbonnier, A., D'incan, E., Mohty, B., Blaise, D. and Vey, N., 2017. Treatment of Post-transplant Relapse of FLT3-ITD Mutated AML Using 5-Azacitidine and Sorafenib Bitherapy. Clinical Lymphoma, Myeloma and Leukemia, 17(4), pp.241-242. 
Smith, B., Kucmin-Bemelmans, I., Alleman, C., Hensen, M., Skikne, B. and Mahmoud, D., 2013, June. Estimates of burden of disease associated with management of acute myeloid leukemia in UK and US. Haematologica (Vol. 98, pp. 211-211).

Stein, E.M., Yang, M., Guerin, A., Gao, W., Galebach, P., Xiang, C.Q., Bhattacharyya, S., Bonifacio, G. and Joseph, G.J., 2018. Assessing utility values for treatment-related health states of acute myeloid leukemia in the United States. Health and quality of life outcomes, 16(1), p.193.

Sung, L., Buckstein, R., Doyle, J.J., Crump, M. and Detsky, A.S., 2003. Treatment options for patients with acute myeloid leukemia with a matched sibling donor: a decision analysis. Cancer: Interdisciplinary International Journal of the American Cancer Society, 97(3), pp.592-600.

Takahashi, K., Kantarjian, H.M., Pemmaraju, N., Borthakur, G., Faderl, S., Garcia-Manero, G., Andreeff, M., Pierce, S., Ravandi, F. and Cortes, J.E., 2011. FLT3 inhibitors are promising salvage therapy for relapsed or refractory acute myeloid leukemia (AML) in patients with FLT3-ITD mutations.

Wolf, J., Camilleri, M., Sheridan, M., Protheroe, R., \& Mehta, P. (2018, April). Management of Adult Acute Myeloid Leukaemia/High Risk Myelodysplastic syndrome in a Tertiary Haematology Unit in the Southwest of the UK: Are Standardised Quality Improvement Indicators needed?. In BRITISH JOURNAL OF HAEMATOLOGY (Vol. 181, pp. 158-158). 111 RIVER ST, HOBOKEN 07030-5774, NJ USA: WILEY.

Xie L., Zhang Q., Baser O., McGuire M., 2017. Examining the health care resource use and economic costs associated with acute myeloid leukemia among medicare patients. Value in Health. Conference: ISPOR 22nd Annual International Meeting. United States. 20 (5) (pp A218), 2017.

Xuan, L., Wang, Y., Huang, F., Wu, B., Fan, Z., Xu, N., Ye, J., Sun, J., Huang, X. and Liu, Q., 2017. The Effect of Sorafenib Therapy on the Outcome of Acute Myeloid Leukemia with FLT3-ITD Undergoing Allogeneic Hematopoietic Stem Cell Transplantation. 